\title{
INVESTMENT, PASS-THROUGH \\ AND EXCHANGE RATES: \\ A CROSS-COUNTRY COMPARISON
}

\author{
Jose Campa \\ Linda S. Goldberg
}

Working Paper No. 5139

\author{
NATIONAL BUREAU OF ECONOMIC RESEARCH \\ 1050 Massachusetts Avenue \\ Cambridge, MA 02138 \\ June 1995
}

Gordon Bodnar, Richard Clarida, Michael Knetter, and participants at the 1995 NBER International Macroeconomics Winter Meeting and Cornell University provided useful comments. This paper is part of NBER's research programs in International Finance and Macroeconomics, and International Trade and Investment. Any opinions expressed are those of the authors and not those of the National Bureau of Economic Research.

() 1995 by Jose Campa and Linda S. Goldberg. All rights reserved. Short sections of text, not to exceed two paragraphs, may be quoted without explicit permission provided that full credit, including $\odot$ notice, is given to the source. 


\title{
INVESTMENT, PASS-THROUGH \\ AND EXCHANGE RATES: \\ A CROSS-COUNTRY COMPARISON
}

\begin{abstract}
Although large changes in real exchange rates have occurred during the past decades, the real implications of these movements remain an empirical question. Using detailed data from the United States, Canada, the United Kingdom, and Japan we examine the implications of exchange rates for time series of sectoral investment. Both theoretically and empirically we show that investment responsiveness to exchange rates varies over time, positively in relation to sectoral reliance on export share and negatively with respect to imported inputs into production. The quantitative importance of each of these channels of exposure is a function of a set of exchange rate pass-through and demand elasticities. There exist important differences in investment endogeneity across high and low markup sectors, with investment in low markup sectors significantly more responsive to exchange rates. Unlike pass-through elasticities, which are viewed as industry-specific, investment endogeneity to exchange rates is a country-specific phenomenon.
\end{abstract}

Jose Campa

Stern School of Business

New York University

44 West 4th Street

New York, NY 10012
Linda S. Goldberg

Department of Economics

New York University

269 Mercer Street, 7th Floor

New York, NY 10003

and NBER 


\section{INTRODUCTION 1}

Despite the substantial movements in real and nominal exchange rates over the past decades, the implications of these movements for real economic activity remain an open question. Exchange rates can cause large shifts in relative unit labor costs and influence the prices of goods sold in domestic and foreign markets. If producers are not perfectly hedged against exchange rate movements, their short and long run profitability, overall levels of investment, and location of production facilities could depend on exchange rates. In this paper we present a cross-country and sectoral analysis of the implications of real exchange rates for investment activity. Before turning to our methodology and empirical results, below we provide a brief overview of the current state of knowledge on a range of real exchange rate effects.

A growing literature has sought to untangle the mechanisms through which countries and industries cope with real exchange rate movements. In recent years, one direction of emphasis of this literature is on the pricing-to-market phenomenon and on pass-through of exchange rates into traded goods prices. ${ }^{2}$ Rudiger Dornbusch (1987) provided a formal derivation of pass-through elasticities under alternative static models of imperfect competition. Ken Froot and Paul Klemperer (1989) formally emphasized the role of dynamic considerations in current pass-through and pricing decisions, emphasizing that the objective of capturing future market share matters for the elasticity of current prices to transitory movements in exchange rates.

Stylized facts have emerged on the pass through and pricing to market characteristics of countries and industries. Catherine Mann (1986) argued that foreign producers appear to adjust their profit margins to achieve stability of dollar prices on goods sold in the United

\footnotetext{
${ }^{1}$ Linda Goldberg is grateful for the research support provided by the C.V. Start Center of Applied Economics.

${ }^{2}$ Paul Krugman (1987) introduced the pricing-to-market terminology, i.e. destination-specific adjustment of markups in response to exchange rate changes
} 
States, while United States producers did not follow analogous pricing policies. Michael Knetter's (1989) analysis of German and United States export prices corroborated these findings. Richard Marston (1990) also provided detailed evidence of local currency pricing-tomarket by Japanese exporters, based on an analysis of the differences between prices of Japanese goods sold in Japan versus for export. ${ }^{3}$ Despite this body of evidence of countryspecific tendencies in pricing, Knetter (1993) shows that the composition of industries in each of these countries may be more important for observed elasticities than pricing behavior endemic to a particular country. Basically, Knetter concludes that pricing-to-market and passthrough elasticities are better described as industry-specific rather than country-specific phenomena.

In addition to influencing the export market prices of domestically produced goods, exchange rate movements also can lead to adjustments in the prices of goods produced and consumed domestically. Robert Feinberg $(1986,1989)$ shows that these forces are statistically significant in both the United States and in Germany. Feinberg argues that the two channels for these effects are through exposure to imported intermediate goods and through price competition on goods competing with imported final products. Phillip Swagel (1995) argues that these effects are qualitatively quite small for the United States.

Pricing is just one dimension of the real effects of exchange rate movements. Crosscountry distinctions may exist in the willingness of producers to absorb exchange rate changes in prices (or profit margins or markups) versus volume adjustment. William Branson and Marston (1989) argue that Japanese producers are willing to adjust profit margins in response

\footnotetext{
${ }^{3}$ Marston's evidence does not rule out that overall product markups and profitability may be stabilized via a combination of altering yen prices on goods sold in protected domestic markets as well as on the goods exported.
} 
to shocks rather than adjust output and employment. By contrast, producers in the United States are much more willing to undertake output and especially employment adjustments. ${ }^{4}$

The combination of price and quantity responses to exchange rate movements should lead to overall endogeneity of profits, stock prices, and resulting long term investment and growth decisions. ${ }^{5}$ The apparently puzzling pattern of this endogeneity has been pointed out by Gordon Bodnar and William Gentry (1993). Their analysis of monthly data on industry returns during the 1980s for two-digit sectors in Canada, Japan and the United States, shows that excess returns are significantly correlated with exchange rates in less than half of the industries. For the United States, elasticities of industry returns with respect to exchange rate depreciation are positively correlated with raw materials input prices and the foreign direct investment share of the sector. For both Canada and Japan, the elasticities of industry returns with respect to exchange rate depreciations are significantly lower for nontraded industries and higher for industries that are export intensive.

The unexpected finding is that so many sectors with significant external exposures exhibit relative insensitivity to exchange rates. Eli Bartov and Bodnar's (1994) offer an explanation of this phenomenon based on market mispricing of foreign exchange exposure. In the present paper, our work suggests that the excess return issue needs to be reexamined. Methodologically, tests of excess returns should take into account the dramatic evolution over time of producer exposure to export markets and reliance on imported inputs. The importance of each of these forces will depend on industry-specific pass-through and demand elasticities. Inclusion of time-varying exposures in regressions should provide a more accurate description of whether profitability is actually responsive to exchange rates. Discussion of the results in

\footnotetext{
${ }^{4}$ Employment endogeneity to exchange rates is documented for United States manufacturing sectors by Branson and Jamie Love (1988). Robert Gordon (1987) presents evidence that Japanese unemployment rates are much lower than those of the United States, Canada, and most European countries.

${ }^{5}$ Richard Clarida (1993), using an error correction model on aggregate United States manufacturing data, concludes that the long-run elasticity of real profits with respect to the real exchange rate exceeds 0.75 .
} 
terms of elasticities provides an alternative testable hypothesis about the weak response of excess returns to exchange rates.

Investments in local and overseas markets also are sensitive to exchange rate movements. Linda Goldberg (1993) and Jose Campa and Goldberg (1995a) show that investment levels in two-digit sectors of United States industry are significantly correlated with exchange rate movements, and the size of this correlation is a function of evolving sectoral export shares and reliance on imported inputs into production. Exchange rate movements have more significant implications for investments in low-markup sectors than for investments in high-markup sectors. The opposite pattern of endogeneity of markups appears in United States industry. These results suggest that industry features, beyond their trade and external exposures, lead to different mechanisms of adjustment to dollar realignments. ${ }^{6}$

In the present paper we provide a broader cross-country look at the linkage between exchange rates and physical investment, and ask whether the importance of exchange rates for investment appears to be an industry-specific or country-specific phenomenon. Theoretically, we emphasize that the linkage between exchange rates and profit rates clearly depends on export share and reliance on imported inputs into production. The quantitative and qualitative importance of each of these exposure terms are shown to depend on a set of exchange rate pass-through coefficients and on sectoral demand elasticities. If investment is an increasing function of the expected discounted stream of a sector's profits, investment endogeneity with respect to exchange rates depends on a set of forces analogous to those which drive sectoral profitability. By influencing investment, exchange rates alter the longer-run growth of an economy: the extent of these forces depend on pricing and pass-through elasticities.

\footnotetext{
6In cross-country studies, Jose Campa (1993) and Linda Goldberg and Charles Kolstad (1995) consider the implications of exchange rate volatility for foreign direct investment. Campa finds that exchange rate volatility reduces foreign direct investment levels, especially in industries where sunk investments in physical and intangible assets are high. Goldberg and Kolstad find that exchange rate volatility increases the share of total production activity that producers locate overseas.
} 
Our analysis uses industry data for the United States, Canada, the United Kingdom, and Japan, for roughly the interval of 1970 through 1990 . We introduce time-varying sectoral export exposure, import competition, and reliance on imported inputs into production. As Campa and Goldberg (1995a) showed, without these time-varying exposure measures an empirical study would tend to understate the importance of exchange rates for real economic activity.

We observe striking patterns of adjustment to exchange rates. Within all countries, an exchange rate depreciation stimulates sectoral investment most when sectors have high export shares and contracts investment most when sectors rely heavily on imported inputs into production. The qualitative importance of this estimated investment endogeneity appears to be a country- not industry-specific phenomenon. In comparison with cross-sectoral results for particular countries, regressions which pool together the same sector from different countries cannot significantly capture the relationship between industry investment and exchange rates. ${ }^{7}$

We also observe that investment responsiveness to exchange rates differs across high and low markup sectors. In high markup sectors investment is relatively unresponsive to exchange rates. In low markup sectors the relationship is more often statistically significant. The pattern of results could suggest that producers in high markup sectors are more effective at absorbing shocks to their overall profitability than are producers in low markup sectors. This could imply that the link between expected profits and investment is weaker for high markup sectors. ${ }^{8}$

\footnotetext{
${ }^{7}$ Another resounding result is that anticipated exchange rate effects on investment and price-over-cost markups are at least an order of magnitude smaller than contemporaneous exchange rate effects. These findings make us much more skeptical about the empirical importance of dynamic pricing based on capturing future market share (Froot and Klemperer, 1989) or based on incentives for implicit collusion.

${ }^{8}$ Mark Gertler and Simon Gilchrist (1994) show that small firms in the United States may be excluded from credit markets when there are overall economic contractions. The firms therefore have reduced access to credit for hedging short term fluctuations. If these small firms are in low markup sectors, their profitability and
} 
An alternative explanation is directly grounded in the profit function of the producers. Since the endogeneity of profitability and investment with respect to exchange rates depend on pass-through and demand elasticities, microeconomic explanations exist for some of the sectoral and country differences in exchange rate effects. Under some models of imperfect competition, such as the Cournot model, pass-through elasticities differ across high and low markup sectors. Cross-country differences in demand elasticities and the responsiveness of domestic prices with respect to exchange rates further help explain the pattern of observed results. 9

The paper is organized as follows. In Section II we formulate a simple structural model of the relationship between exchange rates and investment, wherein current investment is positively related to the discounted stream of current and expected future profits. Exchange rate effects are introduced through both revenue and cost channels, each of which are weighted by a set of price and pass-through elasticities. The size and sign of the pass-through elasticities are discussed in the context of static and dynamic industrial organization models. We pull these arguments together into an integrated presentation which motivates our empirical work.

Section III provides a brief discussion of the data on investment, markups, and the constructed indices of export exposure and imported input exposure. In Section IV we present the results from estimation of simultaneous equation systems of endogenous investment and price-over-cost markups with respect to actual and anticipated exchange rates. ${ }^{10} \mathrm{We}$ differentiate among the implications of exchange rates for investment and markups

investment patterns also may be more significantly influenced by exchange-rate induced fluctuations in demand.

${ }^{9}$ Interestingly, the sectors which Bodnar and Gentry (1993) show bave stock prices relatively unresponsive to exchange rates generally fall within our classifications of high markup sectors.

10If prices are endogenous with respect to exchange rates, under some modes of competition markups also will be endogenous. We permit this endogeneity in the empirical analysis. 
in high and low markup sectors within countries, and also pool individual sectors across countries to provide insights into whether exchange rate effects are endemic to industries or to countries. Section V synthesizes and concludes.

\section{INVESTMENT AND EXCHANGE RATES}

Let a firm choose investment $I_{t}$ to maximize its net present value $V_{t}$ subject to a traditional capital accumulation equation

$$
\begin{aligned}
& V_{t}=\mathrm{E}_{\mathrm{t}}\left[\sum_{j=0}^{\infty}(1+\rho)^{-\mathrm{j}} \pi_{t+j}\left(K_{t+j}, I_{t+j}\right)\right] \\
& K_{t}=(1-\delta) K_{t-1}+I_{t}
\end{aligned}
$$

where $\pi_{t}\left(K_{t}, I_{t}\right)$ represents the maximized value of net cash flow (profits) at time $t, \rho$ is the discount factor, $K_{t}$ is the current capital stock of the firm and $\delta$ is the depreciation rate of capital. $\mathrm{E}$ is the expectations operator.

In an uncertain environment the optimal amount of investment is a function of the discounted future marginal profitability of capital. The firm chooses an $I_{t}$ for which the marginal cost of capital is equal to its expected marginal profitability. Following the adjustment cost literature we assume that the marginal cost is a positive and increasing function of $I_{r}{ }^{11}$ The expected marginal profitability of capital is equal to the expected average profitability for a firm with constant returns to scale participating in a perfectly competitive industry. In this case, investment is a positive function of expected profits, which in turn are modeled as a function of the cost of capital, $r$, the cost of domestic and imported inputs into production, and the expected price of domestic and foreign sales. We write the reduced form relationship for investment in industry $i$ as:

\footnotetext{
${ }^{11}$ Variations on the ex ante cost of capital account for more than half of the cyclical variation in the marginal profitability of capital [Andy Abel and Olivier Blanchard, 1986]
} 


$$
I_{t}^{i}=\phi\left(E_{t} \sum_{j=0}^{\infty} \pi_{t}{ }^{i}\left(p_{i}, e p_{i}^{*}, w, e w^{*}\right), r_{t}\right)
$$

Investment depends on the present and future values of the real exchange rate $e$, defined in terms of domestic currency per unit of foreign exchange; the real prices of good $i$ in domestic and foreign markets, $p_{i}$ and $p_{i}^{*}$; and, $w$ and $e w^{*}$, representing domestic and foreign input costs. ${ }^{12}$

To determine the impact of exchange rates on expected profits for any period $t$, we specify per period variable profits for a representative firm in industry $i$ :

$$
\begin{aligned}
& \pi^{i}=\hat{p}_{i}(e) \cdot q_{i}\left(\hat{p}_{i}\right)+e \hat{p}_{i}^{*}(e) \cdot q_{i}^{*}\left(\hat{p}_{i}^{*}\right)-c_{i}\left(w, e w^{*}, q_{i}\left(\hat{p}_{i}\right)+q_{i}^{*}\left(\hat{p}_{i}^{*}\right), r\right) \\
& \text { with } q_{i}, q_{i}^{*} \geq 0
\end{aligned}
$$

where a "^" over a variable denotes the optimal values obtained from the corresponding maximization problem. $c_{i}\left(w, e, q_{i}+q_{i}^{*}\right)$ is the total cost of producing the aggregated sales for domestic and foreign markets, $q_{i}+q_{i}^{*}$. For the sake of exposition, we assume the firm applies a constant-returns-to-scale Cobb-Douglas production technology with $\alpha^{t}$ representing the share of imported inputs in total home production costs.

Differentiation of equation (4) shows that an exchange rate change alters expected profits according to a combination of elasticities of valuation (price and marginal cost) and volume adjustments. First, we define notation: $\chi^{i}$ is the share of export revenues in total revenues and total revenues in the industry are denoted by $T R^{i}$. Price elasticities with respect to exchange rates on domestically produced goods sold in domestic and foreign markets are denoted by $\eta_{p_{1}}=\left(\frac{\partial p_{i}}{\partial e}\right) /\left(\frac{p_{i}}{e}\right)$ and $\eta_{p_{i}^{*}}=\left(\frac{\partial p_{i^{*}}}{\partial e}\right) /\left(\frac{p_{i^{*}}}{e}\right)$. The domestic and foreign market demand elasticities, as perceived by domestic producers are denoted by

\footnotetext{
${ }^{12}$ Exchange rate volatility easily can be added into this formulation. Altbough Campa and Goldberg (1995a) conclude that exchange rate volatility is not quantitatively important for investment levels in United States manufacturing sectors, this result may not generalize to economies with greater international exposure.
} 
$\theta_{q_{i}}=\left(\frac{\partial q_{i}}{\partial p_{i}}\right) /\left(\frac{q_{i}}{p_{i}}\right)<0$ and $\theta_{q_{i}}=\left(\frac{\partial q_{i^{*}}}{\partial p_{i^{*}}}\right) /\left(\frac{q_{i^{*}}}{p_{i^{*}}}\right)<0$. The imported input price elasticity with respect to the exchange rate is denoted by $\eta_{e^{*}}=\left(\frac{\partial e w^{*}}{\partial e}\right) /\left(\frac{e w^{*}}{e}\right) \cdot \eta_{q+q^{*}}$ is the elasticity of cost due to the exchange-rate induced change in total production volumes. The industry average price-over-cost markup ratio is defined by $M K U P^{i}=\left(T R^{i}-c^{i}(\cdot)\right) / T R^{i}$, where $T R^{i}$ is defined as total revenues. ${ }^{13}$ Prices are chosen optimally by the producer, with sales changes in each market dependent on the shape of the respective demand curves. Differentiation of equation (4) with respect to the exchange rate yields:

$$
\frac{\partial E\left(\pi^{i}\right) / \partial e}{T R^{i} / e}=\chi^{i}\left(1+\eta_{p_{i}}\left(1+\theta_{q_{i}^{i}}\right)\right)+\left(1-\chi^{i}\right) \eta_{p_{i}}\left(1+\theta_{q_{i}}\right)-\alpha^{i}\left(1-M K U P^{i}\right) \eta_{e w^{*}}-\left(1-M K U P^{i}\right) \eta_{q+q^{*}}
$$

Notice the generality of equation (5). It does not impose a particular competitive structure on the market for the good generating revenue for the domestic firm. It also does not impose a particular structure on the market for the imported input good. Instead, it shows which price and demand elasticities are important for the link between exchange rates and profitability. The relevant pass-through elasticities are those on export prices in the destination market currency, $\eta_{p_{i}^{*}}$ imported input prices in the home market currency, $\eta_{e w^{*}}$, and on domestic goods sold in domestic markets, $\eta_{p_{i}}$.

Exchange rates influence expected industry profitability via export exposure, via price adjustments on sales in domestic markets, and via changes in the total cost of production due to movements of the exchange rate. First, the effect of the exchange rate through industry export exposure has two components: a direct valuation effect on existing export revenues of the producers and an indirect effect from the degree of adjustment of the foreign market price and export quantity. Second, the exchange rate may induce changes in the prices and

\footnotetext{
${ }^{13}$ Our markup measure more appropriately could be called the ratio of profits to total revenues. This measure moves monotonically with a more standard measure of total revenues to total costs. Each of these measures would be expected to move monotonically with a marginal revenue (price) to marginal cost markup ratio.
} 
quantities of goods sold domestically, perhaps because of import competition. Finally, the exchange rate can affect costs by altering the domestic currency price of imported inputs and the optimal level of output of the firms. These cost changes enter into overall profitability adjustment in proportion to the importance of costs relative to industry revenues, i.e. in relation to $1-M K U P i$.

We will return to the microeconomic determinants of the size and signs of respective pass-though elasticities under alternative models of imperfect competition. First, however, consider a simple case which illustrates the influence of exchange rates on producer profitability and investment. Suppose that there are no imported inputs into production $(\alpha=0)$. Suppose also that a producer follows a strategy of local currency price stabilization on export sales, i.e. $\eta_{p_{i}^{*}}=0$. The unity term which still multiplies $\chi_{i}$ in $\left(1+\eta_{p_{i}^{*}}\left(1+\theta_{q_{i}^{*}}\right)\right)$ is a pure export revenue valuation effect due to the movement of the exchange rate. The policy of stabilizing foreign market prices of the exported good maintains stable market share and output by the exporter. Although quantities sold abroad are stable, export revenues increase due to the valuation effect, total profitability expands, and this could lead to further domestic investment.

It also is possible that the exchange rate depreciation increases the price of goods sold domestically, $\eta_{p_{i}}>0$, in response to increased prices on competing imported goods, as occurs under Cournot competition. This increase in revenues on domestic sales further increases producer profitability. Notice that the size of this effect depends on $1-\chi^{i}$. The reason for this effect is clearly shown in equation (5). Producer revenues from domestic sales increase only to the extent that production is oriented toward domestic markets. The greater is the export share of the industry, the smaller will be the revenue gains captured by domestic producers from an increase in prices on purely domestic sales.

Suppose that the domestic producer places a very strong premium on domestic output stability. For example, Japanese producers are described as having a higher preference for stable output than United States producers, who in turn stabilize output more than United Kingdom producers. With export market price stability, domestic output stability can only be 
maintained with very small $\eta_{p_{t}}>0$ or, for a given $\eta_{p_{t}}$, with very small demand elasticities (in absolute value). If the demand elasticity is large, domestic producers may keep $\eta_{p_{i}}>0$ low and sacrifice potential profits in order to maintain stable output.

The terms multiplying $\alpha$ in equation (5) are a positive function of $\left(1-M K U P^{i}\right) \eta_{e w}$. The importance of imported input share for the expected profits depends on the extent to which foreign suppliers adjust the local currency price of these inputs in response to domestic currency depreciation. If foreign input suppliers pursue a strategy of complete local-currency price stability, then $\eta_{e w^{*}}=0$, and domestic currency depreciation will not influence imported input costs. Under any other pricing strategy, i.e. under $\eta_{\text {ew* }}>0$, a real domestic currency depreciation presents domestic producers with a cost shock. The relative importance of a cost shock in overall profits depends on the overall ratio of total costs to total revenues, i.e. the weight $\left(1-M K U P^{i}\right) .14$

Price Elasticities with respect to Exchange Rates: The theoretical signs of domestic and foreign market pass-through elasticities depend on the forms of competition within relevant markets. Three different markets are pertinent: the two markets for the final good being produced, which determines $\eta_{p i}$ and $\eta_{p i^{*}}$, and the market for the good used as the imported input, which determines $\eta_{\text {ow* }}>0$. The time horizon for price-setting may be one period, so that static models apply and current prices respond only to observed or actual exchange rate movements. Alternatively, if dynamic considerations influence current pricing decisions, anticipated exchange rates also will matter, along with market perceptions of whether observed exchange rates are temporary or permanent. Table 1 summarizes the implications for exchange rate pass-through elasticities of four models of competition that previously have been developed in the literature.

\footnotetext{
${ }^{14}$ If imported input prices change, this can change the prices of domestic and exported goods.
} 
Under Dixit-Stiglitz monopolistic competition, markups are constant and independent of exchange rate changes. Assuming inputs into production are domestically supplied at exogenous domestic currency wages, domestic prices and quantities supplied by domestic producers are unchanged by a depreciation, i.e. $\eta_{p_{t}}=0$ [Dornbusch (1987)]. The domestic currency price of exports also remains unchanged, so that the foreign currency price of this good falls to offset the domestic currency depreciation, i.e. $\eta_{p_{i}^{*}}=-1$. Quantities sold in foreign markets by domestic producers rise accordingly.

If the monopolistic competitor supplies both domestic and foreign markets and faces variable marginal costs, the exchange-rate pass through elasticities will depend on the overall effects on marginal costs of total changes in the level of production for domestic and foreign markets [Marston (1990)]. It is straight-forward to expand this analysis to a scenario where there are imported input costs. If these costs rise with depreciation, i.e. if $\eta_{w^{*}}>0$, then both domestic and export price elasticities will rise accordingly.

Under static Cournot competition, markup ratios on exported goods rise when the domestic currency depreciates. The domestic producer can undercut foreign competition abroad by lowering the sale price in foreign currency terms at the same time that the domestic currency price of the export has risen. The amount that markups increase in response to a depreciation is negatively related to the degree of foreign competition in the export market. A similar argument holds for the effect of exchange rates on prices of goods sold in domestic markets. The pass-through coefficient depends on the pricing behavior of foreign suppliers participating in this market and on the degree of local import competition [Dornbusch (1987)]. 
Table I Direct Price Elasticities under Alternative Theories of Competition(1)

Direct Price elasticities with respect to actual exchange rate depreciation (2)

\begin{tabular}{|l|c|c|c|}
\hline Static models & $\eta_{\mathrm{p}}$ & $\eta_{\mathrm{p}^{*}}$ & $\eta_{\mathrm{ew}}$ (3) \\
\hline $\begin{array}{l}\text { perfect competition } \\
\begin{array}{l}\text { monopolistic } \\
\text { competition }\end{array}\end{array} 0$ & 0 & 0 & 0 \\
\hline Cournot & $0<\eta_{\mathrm{p}<1}$ & $-1<\eta_{\mathrm{p}^{*}<0}$ & $0<\eta_{\mathrm{ew}}<1$ \\
\hline
\end{tabular}

Direct Price elasticities with respect to anticipated exchange rate depreciation (2)

\begin{tabular}{|l|c|c|c|}
\hline Dynamic models & $\eta_{\mathrm{p}}$ & $\eta_{\mathrm{p}^{*}}$ & $\eta_{\mathrm{ew}}$ (3) \\
\hline market share & $0<\eta_{\mathrm{p}}$ & $\eta_{\mathrm{p}^{*}<0}$ & $0<\eta_{\text {ew* }}$ \\
\hline Implicit Collusion & $\eta_{\mathrm{p}}<0$ & $0<\eta_{\mathrm{p}^{*}}$ & $\eta_{\mathrm{ew}}<0$ \\
\hline
\end{tabular}

(1) The size of these elasticities also depend on the extend to which marginal costs adjust due to overall changes in production quantities. (2) The price elasticities will also adjust to the extent that imported input costs respond to exchange rate movements. (3) The extent of pass-through into imported input prices depends on the form of competition in the input market.

Dynamic models of endogenous markups emphasize both actual and anticipated movements in exchange rates. Froot and Klemperer (1989) derive pass-through elasticities when producers are concerned about maintaining market share over the exchange rate cycle. ${ }^{15}$ Current pricing decisions attempt to maximize the expected discounted value of current and future profits. If switching costs are associated with changing one's supplier, in temporarily low demand periods producers follow pricing strategies aimed at locking in higher market

\footnotetext{
${ }^{15}$ The Froot and Klemperer approach directly follows from the Phelps and Winter (1970) more general analysis of markups over the business cycle.
} 
share for periods when demand is high. Current prices are low when future demand is expected to be high, i.e. when depreciations of the domestic currency are expected. ${ }^{16}$

A second dynamic argument that may pertain to pass-through coefficients is based on implicit collusion, as formalized by Rotemberg and Saloner (1986). The objective of the firm remains the same: current prices are set so as to maximize the expected discounted value of current and future profits. However, suppliers implicitly collude on pricing. Collusion is maintained by the threat that price reductions, which raise current profits of a deviating firm, lead to a price war which lowers future profits. The producer has lower incentives to deviate from the collusive pricing rule when he expects future profits to be high: the (expected discounted value of the) punishment for deviating from the collusive equilibrium is more severe in a low demand period (recesssion) than in a high demand period (boom). Thus, when demand is temporarily low, prices are maintained artificially high: incentives for price collusion are strengthened and prices fall by smaller amounts; when demand expands, prices can rise by larger amounts when incentives for implicit collusion are weakened. Under implicit collusion motives, price and exchange rate pass-through elasticities are in an opposite direction to those predicted by the market share argument.

Equation (5) provides a structural foundation for our testing equation:

$$
\begin{aligned}
\Delta_{t}^{i}= & \beta_{0}^{i}+\beta_{1} \Delta y_{t}^{i}+\left(\beta_{2}+\beta_{3} \chi_{t-1}^{i}+\beta_{4} \alpha_{t-1}^{i}\left(1-M K U P_{t-1}^{i}\right)\right) \Delta e_{t-1} \\
& +\left(\beta_{5}+\beta_{6} \chi_{t-1}^{i}+\beta_{7} \alpha_{t-1}^{i}\left(1-M K U P_{t-1}^{i}\right)\right) \Delta e_{t}^{a}+\beta_{8} \Delta r_{t}+\mu_{t}^{i}
\end{aligned}
$$

where $\Delta$ indicates first differences. $y^{i}$ represents the logarithm of industry sales: the growth rate of sales in the industry is introduced to control for differences in growth rates across industries. Due to the nature of investment activity, we assume that it takes one year before the effects of exchange rates on investment show up in the data. Consequently, a one-period

\footnotetext{
${ }^{16}$ Froot and Klemperer apply this model to export price differentials on annual bilateral trade data for 1981 to 1986 between the United States, United Kingdom, West Germany, France and Japan. They do not find overwhelming evidence that expected future depreciation influences the degree of pricing to market.
} 
lagged rate of change in $e$, the logarithm of the exchange rate, is used to capture the "contemporaneous" exchange rate effect, and the period $t-I$ anticipation of the period $t$ change in the (logarithm of the) exchange rate, $e_{t}^{a}$, is used to capture the effects on current investment of anticipated exchange rate movements. As we have specified the testing equation, two years of exchange rate movements directly influence current investment growth.

In equation (6), exchange rates are permitted to influence investment with constant elasticities (through $\beta_{2}$ and $\beta_{s}$ ) or can vary over time with industry extemal exposure, i.e. with the industry export shares and the markup adjusted imported input shares. From equation (5), we have that the coefficients on the non-interacted exchange rate terms are a positive function of $\eta_{p_{i}}$. The coefficients on the actual and anticipated exchange rates interacted with export share $\left(\beta_{3}\right.$ and $\left.\beta_{6}\right)$ are a positive function of $\left(1+\eta_{p_{i}^{*}}\left(1+\theta_{q_{i}^{*}}\right)-\eta_{p_{i}}\left(1+\theta_{q_{i}}\right)\right)$.

Finally, the coefficient on $\alpha^{i}\left(1-M K U P^{i}\right)$ will be a positive function of $\eta_{w^{*}}$. Since the effect on investment of imported inputs into production is a function of the average markup of the industry, estimation of the investment regressions should account for the likely endogeneity of markups with respect to exchange rates. ${ }^{17}$ Due to data and measurement problems in the construction of markup series, we do not explicitly seek to study the behavior of markups. Instead, our main objective is to control for the comovements between markups and exchange rates, and their resulting effect on investment adjustments. We will instrument and estimate a second equation on the time change of industry markups as a function of changes in the exchange rate. This latter function controls for levels of export orientation, import competition, and imported inputs into production in the sector.

To capture the importance of the dynamic exchange rate pass-through arguments, we require an indicator of anticipated future demand conditions. The current conventional wisdom is that exchange rate movements are typically viewed as permanent rather than

\footnotetext{
${ }^{17}$ Most of the focus of the recent literature on exchange rate movements has been on the behavior of final prices under the assumption of constant marginal costs, and therefore implicitly is focusing on the movement of markups. Dombusch (1987) is a clear example of this.
} 
transitory. This implies that the dynamic models refer to anticipated rather than observed/actual exchange rates. ${ }^{18}$ The static models and related price elasticities are associated with the observed movements in exchange rates. Thus, the relative size of the coefficients on actual versus anticipated exchange rate terms provides us with some perspective regarding the empirical importance of the static versus dynamic pricing arguments.

\section{THE DATA}

In this section we discuss the time series of the exposure of an industry to exchange rates for sectors of United States, Japanese, Canadian and U.K. industries. Three types of time-varying exposure are introduced for each sector of each country: exports relative to total domestic shipments, imports relative to total domestic consumption, and expenditures on imported inputs relative to total production costs. The first two series are straight-forward. The third series, a measure of imported input share, is constructed by the authors using sectoral input-output data for each country according to the following formula: ${ }^{19}$

$$
\alpha_{t}^{i}=\frac{\sum_{j=1}^{n-1} m_{l}^{j} p_{t}^{j} q_{j}^{i}}{\sum_{j=1}^{n-1} p_{t}^{j} q_{j}^{i}+p_{t}^{n} q_{n, t}^{i}}
$$

where $\mathrm{i}=$ index representing the output sector;

$j=$ index representing the production input sector. Out of the $n$ possible input types, the first $n-1$ types correspond to manufacturing and service inputs; the $n^{\text {th }}$ input into production is labor, assumed to be supplied domestically.

\footnotetext{
${ }^{18}$ By contrast, if the current exchange rate movements are perceived to be temporary, the pass-through coefficients of exchange rates predicted by the dynamic models, as related to export share, imported input share, and import competition, are $\beta_{5}-\beta_{2}, \beta_{6}-\beta_{3}$, and $\beta_{7}-\beta_{4}$.

${ }^{19}$ Specific details regarding the data for each country are provided in the Appendix. The original derivation of the index is in Goldberg (1990).
} 
$m_{t} j_{t}=$ share of imports $i$ in new supply of commodity $j$ in period t.

$p_{t}^{j} q_{j, t}^{i}=$ the value of resources from industry $j$ that was used in production of commodity $i$ in period $\mathrm{t}$, defined for $j=1, \ldots n-1$.

$p_{t}^{n} q_{n, t}^{i}=$ annual wage bill in real terms in industry $i$ in period $t$.

The main strengths of these constructed series are that they explicitly utilize production and input-output tables for each country (and for numerous sample years) and combine this information with country data on sectoral imports, exports, total shipments, wage expenditures, and price-over-cost markups. There are two main shortcomings of the imported input series. First, the data on sectoral import shares include both imports of final goods and of intermediate goods of the sector. We cannot determine whether the import share in overall consumption of a good is significantly different from the import share in intermediate input consumption. Second, we generally do not have meaningful or available annual input-output numbers and therefore must sometimes assume that the structure of production (i.e. the shares of particular sectors in total production costs) is inflexible for time horizons of a number of years.

Appendix Table 1 provides summary information about the external exposure of sectors in each country. Included in this table are sectoral sample period averages on export share, imported input share, and the ratio of imports to shipments. Sectors of the Canadian and the UK economies have consistently higher export shares and imported input shares than the US, while the Japanese economy has fewer sectors oriented toward exporting, but higher export shares of these sectors, and generally does not rely heavily on imported inputs into production.

Countries differ tremendously in sectoral exposures and the evolution of these exposures. The United States has the dubious distinction of being the only country with many industrial sectors that have evolved from net exporters to net reliance on imported inputs into 
production. ${ }^{20}$ Comparable results do not arise in the United Kingdom, Japan and Canada when their respective currencies decline in value. Relative to the United States, sectors of United Kingdom industry have had much more stable patterns in net exposure, with net exporters generally remaining net exporters through the end of the 1980s. In Canada many industries have increased their exports share more rapidly than their reliance on imported inputs into production throughout the 1970s and 1980s, leading to overall increases in net export shares. In Japan, there is no single tendency that can characterize net exposures across distinct industries.

Sectoral Markups: Our theoretical derivation of investment exposure to exchange rates yielded elasticities that depended on an average-cost and average-price based measure of price-over-cost markups. We follow the construction methodology of Ian Domowitz, H. Glenn Hubbard and Bruce Petersen (1986), wherein the markup measures account for the behavior of the value of sales and changes in inventories according to:21

$$
M K U P=\frac{\text { value of sales }+\Delta \text { inventories }- \text { payroll }- \text { cost of materials }}{\text { value of sales }+\Delta \text { inventories }}
$$

which is identical to (value added - payroll)/(value added + cost of materials). ${ }^{22}$

\footnotetext{
${ }^{20}$ See Campa and Goldberg (1995b).

${ }^{21}$ Instead of exclusively measuring output as, for example, in Hall (1988). This measure is subject to the usual criticisms, i.e., it does not adequately account for scale economies, capacity utilization, or overhead labor rates. ${ }^{22}$ We use sounce country data for this construction and do not view as appropriate direct cross-country comparisons of levels of markup series. Comparisons within a country of sectoral markup series are probably less problematic but still subject to well-known criticisms. Our main use of the markup series focuses on their rates of change within an industry in relation to exchange rate movements. For this application, we have far fewer misgivings about the series.
} 
Within each country, we rank sectors in order of low to high markup. As shown in Table 2, the rankings within countries are not identical across countries. This finding is expected based on principles of comparative advantage. The United States and Canada are most similar in their rankings of high to low markup sectors. There is little correlation between the rankings of markups, loosely interpreted as sectoral profitability, between the United States or Canada and Japan. The ranking of average sectoral markups by the United Kingdom is most similar to the ranking observed in Japan. The low numbers arising in this comparison of markups across countries can be attributed to various forces. This can reflect stark differences in the relative profitability of production in different sectors of different countries, or differences in the fixed costs of production in sectors across countries that are omitted from the markup construction, or differences in the country accounting procedures for data used in markup construction.

\begin{tabular}{|c|l|l|l|l|}
\hline Table 2 & \multicolumn{4}{|l|}{ Rank correlation between mean Markups across countries } \\
\hline & United States & Canada & United Kingdom & Japan \\
\hline Canada & 0.710 & 1.000 & & \\
\hline U.K. & 0.257 & 0.321 & 1.000 & \\
\hline Japan & 0.168 & 0.018 & 0.514 & 1.000 \\
\hline
\end{tabular}

Estimation of equation (6) also requires both actual and anticipated real exchange rate series. The actual real exchange rate series are trade-weighted indices based on unit labor costs and published in the International Financial Statistics. The anticipated real exchange rate series are more problematic. Froot and Klemperer (1989) used two alternative types of proxy for anticipated real rates. The first type of proxy was based on nominal twelve-month interest rate differentials between the bilateral trading partners, less an expected relative inflation differential which was simply a one-year lag of observed inflation. The second proxy was based on data on expected twelve-month nominal depreciations from surveys by the 
Economist. ${ }^{23}$ These survey data are not available for the 1970 s, a significant part of the sample period that we examine, nor for the array of countries that are used for construction of a trade-weighted real exchange rate index. As a consequence, for each country we use a single measure of anticipated real exchange rate depreciation based on real interest differentials. ${ }^{24}$

\section{IV: EMPIRICAL IMPLEMENTATION AND RESULTS}

In this section we present the results of regressions over sectoral investment data for manufacturing industries in each of the United States, Canada, Japan, and the United Kingdom. The investment series reflect the total amount of investment in plant and equipment within a sector within a country over the course of each year. The data do not identify the owner of the investment activity in domestic markets. Unless otherwise noted in the tables, we report results from a three stage least squares procedure of investment and markups. This procedure allows for the simultaneous determination of interest rates and of markups with respect to exchange rates. For each country, investment regressions are run using pooled data for "all industries", for sectors that are stacked together as "high-markup sectors", and for sectors stacked together as "low-markup sectors". These country results are provided in Tables 3 through 6. The 3SLS results for investment are shown in the first three rows of each table. The estimated markup equations from OLS regressions are reported in the next three rows in each table. 25

Each country has a distinct group of sectors categorized as high versus low markup. The groupings are based on the relationship between a sector's average markup and the

\footnotetext{
${ }^{23}$ Froot and Klemperer provide a brief comparison of the features of altemative survey measures, altemative inflation forecasts, and of resulting measures of expected real depreciation. Jeffrey Frankel and Ken Froot (1989) discuss the availability and features of these survey data in greater depth. Takatoshi Ito (1990) analyzes the relationship between Japanese survey data and actual exchange rate movements.

${ }^{24}$ The appendix provides details on the construction of this measure.

${ }^{25} 2$ SLS runs also were performed, wherein actual not instrumented markups were utilized. The results are qualitatively similar to the $3 S L S$ results.
} 
median average markup over all sectors for that country. ${ }^{26}$ Thus, any comparisons of results across countries identify distinctions in behavior in terms of price-over-cost markup rankings relative to the median, but not in terms of identical industry groups. While there is considerable overlap of sectors within the high and low markup groups across countries, the composition of these groups is not identical for any two countries. For this reason, we also discuss the results from a second set of high and low markup regressions for each country, wherein the sectors in each country are grouped using the United States classification of high versus low markup industries.

In the investment results of Tables 3 to 6 the first three columns of variables show the coefficients and standard errors associated with actual movements in exchange rates, and exchange rate movements interacted with evolving export shares and imported input shares. The next three columns reflect the additional effects of anticipated exchange rate movements. The coefficient on sales growth also is reported. Due to space constraints we do not report industry dummies, industry trends, and interest rate effects. ${ }^{27}$

From each of the country tables, our first main result is that the investment regressions consistently generate the expected signs on the interacted export share terms (positive) and

\footnotetext{
${ }^{26}$ Sectors within the low - markup groupings are: United States - primary metal products, fabricated metal products, transportation equipment, food and kindred products, textile mill products, apparel and mill products, lumber and wood products, furniture and fixtures, paper and allied products, petroleum and coal products, and leather and leather products; Japan - primary metal products, electrical machinery, transportation equipment, textile mill products, lumber and wood products, paper and allied products, printing and publishing, and rubber and plastic products; United Kingdom - primary metal products, fabricated metal products, nonelectrical machinery, electrical machinery, transportation equipment, textile mill products, paper and allied products, printing and publishing, rubber and plastic products, and leather and leather products; Canada - primary metal products, fabricated metal products, transportation equipment, food and kindred products, textile mill products, lumber and wood products, furniture and fixtures, petroleum and coal products, and rubber and plastic products.

${ }^{27}$ The R2's are not reported for the 3SLS investment regressions, since these are not a meaningful measure of fit in these procedures.
} 
imported input share terms (negative). The signs of these coefficients are supported for both actual and anticipated exchange rate movements. Also observe that the size of the coefficients on the actual exchange rate terms are typically an order of magnitude greater than the size of the coefficients on the anticipated exchange rate terms. Despite these consistent patterns, there are important differences in the investment endogeneity within countries and across countries. Below we briefly highlight these additional country-specific findings. The presentation of country results is followed by a discussion of cross-country and sectoral differences in investment endogeneity.

Investment and Markups in the United States: In high markup sectors of United States industry, the effects of exchange rates on physical investment are statistically insignificant. In low markup sectors of United States industry, the effects of exchange rates on investment are large and statistically significant: dollar depreciations significantly stimulate investment in relation to export exposure, and contract investment in relation to reliance on imported inputs into production. ${ }^{28}$

Consider the quantitative importance of these effects. In low markup sectors, on average, if a producer exports all of his output and does not rely on imported inputs, an actual 10 percent depreciation of the dollar will lead to investment expansion of 4.54 percent over the next year. More realistically, if a producer has both export share and imported input shares of 5 percent, investment will expand only by 0.065 percent. A producer who does not export but who relies heavily on imported inputs, on the order of 10 percent, on average will experience an investment contraction of 3.32 percent. The distribution of producer effects clearly is determined by the composition and extent of external exposure.

\footnotetext{
${ }^{28}$ In the 1980s many sectors of United States industry had imported input shares exceeding export shares. The size of the estimated coefficients on these terms could suggest that depreciations depress investment in a majority of sectors of United States industry in the 1980s. See also Goldberg (1993) and Campa and Goldberg (1995a).
} 
Table 3 Endogenous Investment and Markups, by Country, Pooled across Industries: United States, 1972-1986

$$
\Delta I_{t}^{i}=\beta_{0}^{i}+\beta_{1} \Delta y_{t}^{i}+\left(\beta_{2}+\beta_{3} \chi_{t-1}^{i}+\beta_{4} \alpha_{t-1}^{i}\left(1-M K U P_{t-1}^{i}\right)\right) \Delta e_{t-1}+\left(\beta_{5}+\beta_{6} \chi_{t-1}^{i}+\beta_{7} \alpha_{t-1}^{i}\left(1-M K U P_{t-1}^{i}\right)\right) \Delta e_{t}^{a}+\beta_{8} \Delta r_{t}+\mu_{t}^{i}
$$

$\Delta M K U P_{t}^{i}=\delta_{0}^{i}+\delta_{1}^{i} \cdot \operatorname{trend}_{t}^{i}+\left(\delta_{2}+\delta_{3} \chi_{t-1}^{i}+\delta_{4} \alpha_{t-1}^{i}+\delta_{5} M_{t-1}^{i}\right) \Delta e_{t}+\left(\delta_{6}+\delta_{7} \chi_{t-1}^{i}+\delta_{8} \alpha_{t-1}^{i}+\delta_{9} M_{t-1}^{i}\right) \Delta e_{t+1}^{a}+\delta_{10} \Delta y_{t}^{i}+u_{t}^{i}$

\begin{tabular}{|c|c|c|c|c|c|c|c|c|c|c|}
\hline INVESTMENT & e & $\chi^{\mathbf{i} \cdot e}$ & $\begin{array}{c}\boldsymbol{\alpha}^{\mathbf{i}} \cdot \\
\text { (1-MKUP) e }\end{array}$ & & $\mathbf{e}^{\mathfrak{a}}$ & $\chi^{i} \cdot e^{a}$ & $\begin{array}{c}\alpha^{\mathbf{i} .} \\
(1-M K U P) \mathrm{e}^{\mathrm{a}}\end{array}$ & & $\begin{array}{c}\text { sales } \\
\text { growth }\end{array}$ & \\
\hline $\begin{array}{c}\text { All Industries } \\
\text { 3SLS } \\
\end{array}$ & $\begin{array}{c}0.996 \\
(1.015) \\
\end{array}$ & $\begin{array}{c}0.071 \\
(0.044) \\
\end{array}$ & $\begin{array}{l}-0.206 \\
(0.198) \\
\end{array}$ & & $\begin{array}{l}0.021^{*} \\
(0.012)\end{array}$ & $\begin{array}{r}-0.48 \mathrm{E}-3 \\
(0.69 \mathrm{E}-3) \\
\end{array}$ & $\begin{array}{c}-0.20 \mathrm{E}-2 \\
(0.23 \mathrm{E}-2)\end{array}$ & & $\begin{array}{c}0.856^{* * *} \\
(0.108)\end{array}$ & \\
\hline $\begin{array}{c}\text { High Markup } \\
\text { 3SLS }\end{array}$ & $\begin{array}{c}0.280 \\
(1.175) \\
\end{array}$ & $\begin{array}{r}0.69 \mathrm{E}-2 \\
(0.074) \\
\end{array}$ & $\begin{array}{c}-0.049 \\
(0.350) \\
\end{array}$ & & $\begin{array}{c}0.95 \mathrm{E}-2 \\
(0.017) \\
\end{array}$ & $\begin{array}{c}-0.15 \mathrm{E}-2 \\
(0.11 \mathrm{E}-2)\end{array}$ & $\begin{array}{c}0.16 \mathrm{E}-2 \\
(0.47 \mathrm{E}-2) \\
\end{array}$ & & $\begin{array}{c}1.265^{* * *} \\
(0.252) \\
\end{array}$ & \\
\hline $\begin{array}{c}\text { Low Markup } \\
\text { 3SLS }\end{array}$ & $\begin{array}{c}0.912 \\
(1.275) \\
\end{array}$ & $\begin{array}{c}0.454^{* * *} \\
(0.106) \\
\end{array}$ & $\begin{array}{l}-0.415^{*} \\
(0.241) \\
\end{array}$ & & $\begin{array}{c}0.021 \\
(0.015)\end{array}$ & $\begin{array}{c}0.33 \mathrm{E}-2^{*} \\
(0.16 \mathrm{E}-2)\end{array}$ & $\begin{array}{l}-0.48 \mathrm{E}-2 * \\
(0.27 \mathrm{E}-2)\end{array}$ & & $\begin{array}{c}0.730^{* * *} \\
(0.120)\end{array}$ & \\
\hline MARKUP & e & $\chi^{\mathbf{i} \cdot e}$ & $\boldsymbol{\alpha}^{\mathbf{i}} \cdot \mathbf{e}$ & Mi.e & $\mathbf{e}^{\mathbf{a}}$ & $\chi^{i} \cdot e^{a}$ & $\alpha^{i} \cdot e^{a}$ & $\mathbf{M}^{\mathbf{i}} \cdot \mathrm{e}^{\mathbf{a}}$ & $\begin{array}{c}\text { sales } \\
\text { growth }\end{array}$ & $\begin{array}{l}\text { adj } \\
\text { R2 } \\
\end{array}$ \\
\hline All Industries & $\begin{array}{c}0.168 \\
(0.240) \\
\end{array}$ & $\begin{array}{c}-0.040^{* * *} \\
(0.016) \\
\end{array}$ & $\begin{array}{c}-0.017 \\
(0.018) \\
\end{array}$ & $\begin{array}{c}0.056 \\
(0.044) \\
\end{array}$ & $\begin{array}{c}0.008^{* * *} \\
(0.003) \\
\end{array}$ & $\begin{array}{c}-0.19 \mathrm{E}-3 \\
(0.21 \mathrm{E}-3) \\
\end{array}$ & $\begin{array}{c}-0.90 \mathrm{E}-4 \\
(0.46 \mathrm{E}-3) \\
\end{array}$ & $\begin{array}{c}-0.19 \mathrm{E}-3 \\
(0.19 \mathrm{E}-3) \\
\end{array}$ & $\begin{array}{l}0.104^{* *} \\
(0.049) \\
\end{array}$ & 0.086 \\
\hline All Industries & & $\begin{array}{c}-0.034^{* * *} \\
(0.016) \\
\end{array}$ & $\begin{array}{c}0.069 * * * \\
(0.033)\end{array}$ & $\begin{array}{c}-0.021 \\
(0.018) \\
\end{array}$ & & $\begin{array}{r}-0.16 \mathrm{E}-4 \\
(0.21 \mathrm{E}-3)\end{array}$ & $\begin{array}{c}0.74 \mathrm{E}-3 * * * \\
(0.34 \mathrm{E}-3) \\
\end{array}$ & $\begin{array}{c}-0.35 \mathrm{E}-3^{* *} \\
(0.18 \mathrm{E}-3)\end{array}$ & $\begin{array}{c}0.136^{* * *} \\
(0.049)\end{array}$ & 0.057 \\
\hline $\begin{array}{l}\text { High Markup } \\
\text { (US ranking) }\end{array}$ & $\begin{array}{c}-0.546 * * * \\
(0.176) \\
\end{array}$ & $\begin{array}{l}-0.017^{*} \\
(0.010) \\
\end{array}$ & $\begin{array}{c}0.149 * * * \\
(0.044)\end{array}$ & $\begin{array}{c}-0.045^{* * *} \\
(0.015) \\
\end{array}$ & $\begin{array}{c}0.007 * * * \\
(0.002)\end{array}$ & $\begin{array}{c}0.82 \mathrm{E}-4 \\
(0.13 \mathrm{E}-3)\end{array}$ & $\begin{array}{c}-.12 \mathrm{E}-2 * * * \\
(0.45 \mathrm{E}-3)\end{array}$ & $\begin{array}{c}0.25 \mathrm{E}-3 \\
(0.16 \mathrm{E}-3)\end{array}$ & $\begin{array}{c}0.213^{* * *} \\
(0.043)\end{array}$ & 0.430 \\
\hline $\begin{array}{l}\text { Low Markup } \\
\text { (US ranking) }\end{array}$ & $\begin{array}{l}0.681^{*} \\
(0.392)\end{array}$ & $\begin{array}{l}-0.075 \\
(0.047)\end{array}$ & $\begin{array}{c}0.028 \\
(0.066)\end{array}$ & $\begin{array}{l}-0.013 \\
(0.027) \\
\end{array}$ & $\begin{array}{c}0.009^{* * *} \\
(0.005)\end{array}$ & $\begin{array}{c}0.20 \mathrm{E}-3 \\
(0.64 \mathrm{E}-3)\end{array}$ & $\begin{array}{c}-0.14 \mathrm{E}-3 \\
(0.71 \mathrm{E}-3)\end{array}$ & $\begin{array}{c}-0.27 \mathrm{E}-3 \\
(0.28 \mathrm{E}-3)\end{array}$ & $\begin{array}{c}0.050 \\
(0.074)\end{array}$ & 0.064 \\
\hline
\end{tabular}

Each equation has been corrected for first order serial correlation. standard errors reported under the parameter estimates. ***,**,* Significant at the 1,5 and 10 percent level, 2-tailed test. 
A model of Cournot competition is consistent with our finding that the coefficient on the interacted export share term (on $\chi_{i} \cdot e$ ) is smaller for high markup sectors than for low markup sectors. This result arises under Cournot competition because $\left|\eta_{p_{r}}\right|$ for high markup exceeds $\left|\eta_{p_{e}}\right|$ for low markup sectors. For the United States it is unlikely that the differences in the export share coefficients are due to differences in $\eta_{p_{1}}$ across high and low markup sectors, given the existing empirical evidence that the domestic price elasticity with respect to exchange rates is low and often statistically insignificant. Both Feinberg (1989) and Swagel (1995) conclude that the elasticities of United States domestic prices with respect to exchange rates are small but still differ substantially across industries. ${ }^{29}$

Cost shocks associated with reliance on imported inputs, captured by the interacted term $\alpha_{i} \cdot e$, were only statistically significant for investment in low markup sectors. This suggests that the prices of imported inputs into these sectors are sensitive to exchange rate movements: a result contrary to the assertion of complete local-currency-price stability on inputs into low markup sectors of United States industry. ${ }^{30}$ The statistical insignificance of the imported inputs into high markup sectors is more consistent with stable prices on the imported inputs utilized by these sectors. Also notice that the cost shocks have different proportional effects on high versus low markup sectors because each is multiplied by $\left(1-M K U P_{i}\right)$. Since this multiplier is higher for low markup sectors, any cost shock necessarily has a greater proportionate effects on sectoral profitability. This result arises simply because, by definition, costs take a bigger fraction of revenues in low markup sectors.

Finally, notice that we also report in Table 3 the effects of actual and anticipated exchange rates on the total MKUP measures. Actual and anticipated dollar depreciations have significant effects on markups in both high and low markup sectors. The overall effect of

\footnotetext{
${ }^{29}$ However, sectoral imported input shares significantly enhanced $\eta_{p_{1}}$ and the sector's capital intensity of production significantly reduced $\eta_{p_{i}}$. Also see Mann (1994).

${ }^{30} \mathrm{An}$ alternative possible explanation is that, given the high correlation between imports in the industry and imported inputs, this result reflects the effect of import competition.
} 
actual exchange rates on high markup sectors is a reduction in markup. This could be caused by a combination of price reduction and cost increase. By contrast, the dollar depreciation led to an increased markup in low markup sectors (although it should be noted that the fit of the regression was generally quite poor). Anticipated exchange rates have extremely small and quantitatively unimportant effects on markups in two-digit sectors of all groups of sectors of United States industry. At the level of aggregation of our data, we do not find strong evidence for strategic pricing in United States industry to capture dynamic market share or to implicitly collude. At best, the strategic pricing motives are significantly less convincing than more static effects of exchange rates on prices.

Investment and Markups in Japan: Table 4 shows that both high and low markup sectors in Japan exhibit significant investment endogeneity with respect to actual and anticipated exchange rate movements. As observed for the United States and as predicted by the theory, depreciations of the yen stimulate investment in relation to an industry's export exposure and depress investment in relation to imported input shares. Quantitatively, the effects of actual exchange rate movements are much more important for current investment than are anticipated exchange rate movements.

In Japan, actual exchange rates also have a larger impact on physical investment in low markup sectors than they do on physical investments by high markup sectors. As observed for the United States, the role of imported inputs into production is significant only for low markup sectors. Again, the regression results suggest a different pattern of local currency price stability across low and high markup sector inputs.

The coefficients on the statistically significant exchange rate terms in the investment regressions for Japan are much smaller than the analogous terms in regressions for the United States. One explanation for this result is based on the set of elasticities which multiply export 
Table 4 Endogenous Investment and Markups, by Country, Pooled across Industries: Japan, 1974-1990

$$
\Delta I_{t}^{i}=\beta_{0}^{i}+\beta_{1} \Delta y_{t}^{i}+\left(\beta_{2}+\beta_{3} \chi_{t-1}^{i}+\beta_{4} \alpha_{t-1}^{i}\left(1-M K U P_{t-1}^{i}\right)\right) \Delta e_{t-1}+\left(\beta_{5}+\beta_{6} \chi_{t-1}^{i}+\beta_{7} \alpha_{t-1}^{i}\left(1-M K U P_{t-1}^{i}\right)\right) \Delta e_{t}^{a}+\beta_{8} \Delta r_{t}+\mu_{t}^{i}
$$

$\Delta M K U P_{t}^{i}=\delta_{0}^{i}+\delta_{1}^{i} \cdot \operatorname{trend}_{t}^{i}+\left(\delta_{2}+\delta_{3} \chi_{t-1}^{i}+\delta_{4} \alpha_{t-1}^{i}+\delta_{5} M_{t-1}^{i}\right) \Delta e_{t}+\left(\delta_{6}+\delta_{7} \chi_{t-1}^{i}+\delta_{8} \alpha_{t-1}^{i}+\delta_{9} M_{t-1}^{i}\right) \Delta e_{t+1}^{a}+\delta_{10} \Delta y_{t}^{i}+u_{t}^{i}$

\begin{tabular}{|c|c|c|c|c|c|c|c|c|c|c|}
\hline INVESTMENT & e & $\chi^{i} \cdot e$ & $\begin{array}{c}\boldsymbol{\alpha}^{\mathbf{i}} \cdot(1-M K U P) \\
e\end{array}$ & & $e^{a}$ & $\chi^{i} \cdot e^{a}$ & $\begin{array}{c}\alpha^{\mathrm{i}} . \\
(1-\mathrm{MKUP}) \mathrm{e}^{\mathrm{a}}\end{array}$ & & $\begin{array}{c}\text { sales } \\
\text { growth }\end{array}$ & \\
\hline $\begin{array}{c}\text { All Industries } \\
\text { 3SLS } \\
\end{array}$ & $\begin{array}{c}-0.769 * \\
(0.412) \\
\end{array}$ & $\begin{array}{c}0.050^{* *} \\
(0.020)\end{array}$ & $\begin{array}{c}-0.057 \\
(0.034) \\
\end{array}$ & & $\begin{array}{r}-0.30 \mathrm{E}-2 \\
(0.86 \mathrm{E}-2) \\
\end{array}$ & $\begin{array}{c}0.12 \mathrm{E}-2 * * * \\
(0.46 \mathrm{E}-3)\end{array}$ & $\begin{array}{c}-0.92 \mathrm{E}-3 * \\
(0.54 \mathrm{E}-3)\end{array}$ & & $\begin{array}{c}0.575^{* * *} \\
(0.135)\end{array}$ & \\
\hline $\begin{array}{l}\text { High Markup } \\
\text { 3SLS J-rank }\end{array}$ & $\begin{array}{r}-0.615 \\
(0.480) \\
\end{array}$ & $\begin{array}{c}0.041^{*} \\
(0.023) \\
\end{array}$ & $\begin{array}{r}-0.039 \\
(0.035) \\
\end{array}$ & & $\begin{array}{c}0.60 \mathrm{E}-2 \\
(0.95 \mathrm{E}-2) \\
\end{array}$ & $\begin{array}{l}0.96 \mathrm{E}-3^{*} \\
(0.52 \mathrm{E}-3)\end{array}$ & $\begin{array}{l}-0.11 \mathrm{E}-2^{*} \\
(0.52 \mathrm{E}-3)\end{array}$ & & $\begin{array}{c}0.480^{* * *} \\
(0.151)\end{array}$ & \\
\hline $\begin{array}{l}\text { Low Markup } \\
\text { 3SLS J-rank }\end{array}$ & $\begin{array}{r}-0.684 \\
(0.713) \\
\end{array}$ & $\begin{array}{c}0.065^{* *} \\
(0.032)\end{array}$ & $\begin{array}{c}-0.168 * * \\
(0.084)\end{array}$ & & $\begin{array}{l}-0.011 \\
(0.016) \\
\end{array}$ & $\begin{array}{l}0.15 E-2 * \\
(0.83 E-3)\end{array}$ & $\begin{array}{l}-0.98 \mathrm{E}-3 \\
(0.15 \mathrm{E}-2)\end{array}$ & & $\begin{array}{r}0.466 \\
(0.287) \\
\end{array}$ & \\
\hline MARKUP & ER & $\chi^{\mathrm{i} \cdot E R}$ & $\alpha^{\mathbf{i}} \cdot \mathbf{E R}$ & $M^{i} \cdot E R$ & $\mathbf{E R}^{\mathbf{a}}$ & $\chi^{\mathbf{i} \cdot \mathrm{ER}^{\mathbf{a}}}$ & $\alpha^{\mathbf{i}} \cdot \mathrm{ER}^{\mathrm{a}}$ & $\mathbf{M}^{\mathbf{i}} \cdot \mathbf{E R}^{\mathbf{a}}$ & $\begin{array}{c}\text { sales } \\
\text { growth }\end{array}$ & $\begin{array}{l}\text { adj } \\
\text { R2 } \\
\end{array}$ \\
\hline All Industries & $\begin{array}{c}-0.324^{* *} \\
(0.171) \\
\end{array}$ & $\begin{array}{c}0.51 \mathrm{E}-2 \\
(0.010)\end{array}$ & $\begin{array}{c}-0.036 * * * \\
(0.010) \\
\end{array}$ & $\begin{array}{c}-0.75 E-3 \\
(0.017) \\
\end{array}$ & $\begin{array}{c}0.68 E-2 \\
(0.65 E-2)\end{array}$ & $\begin{array}{r}-0.63 E-4 \\
(0.39 E-3) \\
\end{array}$ & $\begin{array}{c}-0.42 E-3 \\
(0.37 E-3) \\
\end{array}$ & $\begin{array}{r}-0.82 E-3 \\
(0.68 E-3) \\
\end{array}$ & $\begin{array}{c}-0.143^{* *} \\
(0.066) \\
\end{array}$ & 0.357 \\
\hline High Markup & $\begin{array}{r}-0.010 \\
(0.272) \\
\end{array}$ & $\begin{array}{r}-0.017 \\
(0.018) \\
\end{array}$ & $\begin{array}{c}-0.054^{* * *} \\
(0.014) \\
\end{array}$ & $\begin{array}{r}0.011 \\
(0.042) \\
\end{array}$ & $\begin{array}{c}0.014 \\
(0.010) \\
\end{array}$ & $\begin{array}{l}-0.31 E-3 \\
(0.69 E-3)\end{array}$ & $\begin{array}{c}-0.10 \mathrm{E}-2 * * \\
(0.51 \mathrm{E}-3) \\
\end{array}$ & $\begin{array}{r}-0.36 \mathrm{E}-3 \\
(0.16 \mathrm{E}-2) \\
\end{array}$ & $\begin{array}{c}-0.186^{* *} \\
(0.092) \\
\end{array}$ & 0.460 \\
\hline Low Markup & $\begin{array}{c}-0.597^{* * *} \\
(0.211)\end{array}$ & $\begin{array}{c}0.017 \\
(0.013) \\
\end{array}$ & $\begin{array}{c}0.033 \\
(0.058)\end{array}$ & $\begin{array}{r}-0.032 \\
(0.039) \\
\end{array}$ & $\begin{array}{c}0.17 \mathrm{E}-2 \\
(0.80 \mathrm{E}-2)\end{array}$ & $\begin{array}{c}-0.63 E-4 \\
(0.49 E-3)\end{array}$ & $\begin{array}{c}0.10 \mathrm{E}-2 \\
(0.20 \mathrm{E}-2)\end{array}$ & $\begin{array}{l}-0.15 \mathrm{E}-2 \\
(0.20 \mathrm{E}-2)\end{array}$ & $\begin{array}{l}-0.060 \\
(0.096)\end{array}$ & 0.244 \\
\hline
\end{tabular}

Each equation has been corrected for first order serial correlation. standard errors reported under the parameter estimates. ***,**,* Significant at the 1,5 and 10 percent level, 2-tailed test. 
share in equation (5). ${ }^{31}$ Recall that the coefficient on $\chi_{i} \cdot e$ is given by a positive function of $\left(1+\eta_{p_{i}}\left(1+\theta_{q_{i}}\right)-\eta_{p_{i}}\left(1+\theta_{q_{i}}\right)\right)$. The components of this expression suggest why, controlling for export exposure, industry profitability and investment in Japan may be less sensitive to exchange rates than their counterparts in the United States. $\left|\eta_{p_{t}}\right|$ for Japanese industries, on average, will be smaller than those for United States industries. Thus, in order for the interacted coefficient on the export share term for Japan to be smaller than the coefficient for the United States, $\eta_{p_{i}}$ must be larger in Japan, possibly combined with a lower demand elasticity. ${ }^{32}$

Marston (1990) shows that actual movements in exchange rates had significant implications for Japanese export prices relative to domestic sale prices on manufactured goods. Using our notation, Marston presents evidence on $1+\eta_{p_{1}^{*}}-\eta_{p_{1}}$. The overall size of this term ranged from approximately 1 to 0.5 and below. ${ }^{33}$ If $\eta_{p_{1}}$ is near zero, these numbers suggest the quantitative importance of $\eta_{p_{t}}$, domestic price endogeneity with respect to exchange rates: ranging from near zero on the first group of products to in excess of 0.5 for the second group of products. Branson and Marston (1989) also found that Japanese output levels exhibit relatively little sensitivity to exchange rates. If $\eta_{p_{i}^{*}}$ is near zero, output stability in Japan can only be supported if Japanese consumers have very inelastic demand for their own products $\left(\theta_{q_{t}}\right.$ close to zero).

\footnotetext{
${ }^{31}$ An alternative explanation for the lower regression coefficients on the exchange rate terms is that the linkage between current profitability and investment spending may be much weaker in Japan. Credit markets in Japan play a more active role in smoothing the effects of exchange rate movements.

${ }^{32}$ If Japan's markets are more protected from foreign competition than those of the United States, the demand elasticities perceived by Japanese firms are likely to be smaller, even if taste parameters are otherwise identical. Knetter (1994), for example, finds evidence of a relatively high degree of discriminatory practices against imports. Prices of German shipments to Japan appear to be significantly higher than prices of shipments to the United States, the United Kingdom, and Canada.

${ }^{33}$ Approximately 1 on Tires and Tubes, Passenger Cars, Tape Recorders, and Amplifiers, to approximately .5 and below on small passenger cars, agricultural tractors, color TVs, microwave ovens, copying machines and cameras.
} 
Smaller regression coefficients on the exchange rate terms for Japan do not imply that exchange rates have a lesser effect on investment in Japan than in the United States. Important sectors of Japanese industry export over 25 percent of their output, while most sectors do not have imported input shares which exceed 5 percent of costs. Following a 10 percent appreciation of the yen, the producer who exports 25 percent will contract investment by 0.1025 percent if he is in a high markup sector. For comparision, recall that investments in high markup sectors of United States industry were not significantly responsive to exchange rates. In low markup sectors of Japanese industry, a producer with 25 percent export share and 3 percent imported input share will contract investment by 0.118 percent. ${ }^{34}$ This effect is twice the size of the effect on investments undertaken by a benchmark low-markup-sector producer in the United States.

Investment and Markups in the United Kingdom: In the United Kingdom, real depreciations of the pound sterling stimulate investment in relation to export share and contract investment in relation to reliance on imported inputs into production. Actual exchange rates, however, have a statistically significant effect only on investments in high markup sectors of United Kingdom industry. Real depreciations of the pound stimulate investment in United Kingdom high markup sectors: this stimuli is strongest when sectors are less dependent on imported inputs into production. This result contrasts with the results for both the United States and Japan. Anticipated exchange rate movements have no effect on current United Kingdom investment activity (or markups). Investments in low markup sectors of the United Kingdom are unresponsive to exchange rates.

The markup equations provide indirect evidence on the elasticity of average sale prices with respect to exchange rates. Pound depreciations significantly increase markups in high and low markup sectors of the United Kingdom. The expansion of markups is mitigated slightly

\footnotetext{
${ }^{34}$ Assuming MKUP is 0.15 for low markup sectors.
} 
Table 5 Endogenous Investment and Markups, by Country, Pooled across Industries: United Kingdom, 1974-1990

$$
\Delta I_{t}^{i}=\beta_{0}^{i}+\beta_{1} \Delta y_{t}^{i}+\left(\beta_{2}+\beta_{3} \chi_{t-1}^{i}+\beta_{4} \alpha_{t-1}^{i}\left(1-M K U P_{t-1}^{i}\right)\right) \Delta e_{t-1}+\left(\beta_{5}+\beta_{6} \chi_{t-1}^{i}+\beta_{7} \alpha_{t-1}^{i}\left(1-M K U P_{t-1}^{i}\right)\right) \Delta e_{t}^{a}+\beta_{8} \Delta r_{t}+\mu_{t}^{i}
$$

$\Delta M K U P_{t}^{i}=\delta_{0}^{i}+\delta_{1}^{i} \cdot \operatorname{trend} d_{t}^{i}+\left(\delta_{2}+\delta_{3} \chi_{t-1}^{i}+\delta_{4} \alpha_{t-1}^{i}+\delta_{5} M_{t-1}^{i}\right) \Delta e_{t}+\left(\delta_{6}+\delta_{7} \chi_{t-1}^{i}+\delta_{8} \alpha_{t-1}^{i}+\delta_{9} M_{t-1}^{i}\right) \Delta e_{t+1}^{a}+\delta_{10} \Delta y_{t}^{i}+u_{t}^{i}$

\begin{tabular}{|c|c|c|c|c|c|c|c|c|c|c|}
\hline INVESTMENT & e & $\chi^{i} \cdot e$ & $\begin{array}{c}\alpha^{\mathbf{i} .} \\
(1-M K U P) \text { e }\end{array}$ & & $\mathrm{e}^{\mathrm{a}}$ & $\chi^{i} \cdot e^{a}$ & $\begin{array}{c}\alpha^{\mathbf{i}} \\
(1-\mathrm{MKUP}) \mathrm{e}^{\mathrm{a}}\end{array}$ & & $\begin{array}{c}\text { sales } \\
\text { growth }\end{array}$ & \\
\hline $\begin{array}{c}\text { All Industries } \\
\text { 3SLS }\end{array}$ & $\begin{array}{c}0.643 \\
(0.530) \\
\end{array}$ & $\begin{array}{c}-0.30 \mathrm{E}-2 \\
(0.69 \mathrm{E}-2)\end{array}$ & $\begin{array}{c}-0.97 \mathrm{E}-3 \\
(0.041) \\
\end{array}$ & & $\begin{array}{c}-0.30 \mathrm{E}-2 \\
(0.014)\end{array}$ & $\begin{array}{c}0.18 \mathrm{E}-3 \\
(0.17 \mathrm{E}-3)\end{array}$ & $\begin{array}{r}-0.70 \mathrm{E}-3 \\
(0.11 \mathrm{E}-2) \\
\end{array}$ & & $\begin{array}{c}0.531^{* * *} \\
(0.114) \\
\end{array}$ & \\
\hline $\begin{array}{c}\text { High Markup } \\
\text { 3SLS }\end{array}$ & $\begin{array}{c}1.384^{* * *} \\
(0.567) \\
\end{array}$ & $\begin{array}{c}0.76 \mathrm{E}-2 \\
(0.78 \mathrm{E}-2)\end{array}$ & $\begin{array}{l}-0.090^{*} \\
(0.053) \\
\end{array}$ & & $\begin{array}{c}-0.65 \mathrm{E}-2 \\
(0.016) \\
\end{array}$ & $\begin{array}{c}0.14 \mathrm{E}-3 \\
(0.19 \mathrm{E}-3)\end{array}$ & $\begin{array}{c}-0.65 \mathrm{E}-3 \\
(0.16 \mathrm{E}-2)\end{array}$ & & $\begin{array}{c}0.232 \\
(0.148) \\
\end{array}$ & \\
\hline $\begin{array}{c}\text { Low Markup } \\
\text { 3SLS } \\
\end{array}$ & $\begin{array}{c}-0.031 \\
(0.626) \\
\end{array}$ & $\begin{array}{c}-0.043 \\
(0.029) \\
\end{array}$ & $\begin{array}{c}0.083 \\
(0.056) \\
\end{array}$ & & $\begin{array}{c}-0.36 \mathrm{E}-2 \\
(0.018)\end{array}$ & $\begin{array}{c}0.36 \mathrm{E}-3 \\
(0.56 \mathrm{E}-3) \\
\end{array}$ & $\begin{array}{c}-0.65 E-3 \\
(0.14 \mathrm{E}-2)\end{array}$ & & $\begin{array}{c}1.013^{* * *} \\
(0.188)\end{array}$ & \\
\hline MARKUP & e & $\chi^{i} \cdot e$ & $\alpha^{i} \cdot e$ & $\mathbf{M}^{\mathrm{i}} \cdot \mathbf{e}$ & $\mathrm{e}^{\mathrm{a}}$ & $\chi^{\mathrm{i} \cdot \mathrm{e}^{\mathrm{a}}}$ & $\alpha^{i} \cdot e^{a}$ & $M^{i} \cdot e^{a}$ & $\begin{array}{c}\text { sales } \\
\text { growth }\end{array}$ & $\operatorname{adj} \mathbf{R} 2$ \\
\hline All Industries & $\begin{array}{l}1.601^{* *} \\
(0.650)\end{array}$ & $\begin{array}{c}0.18 \mathrm{E}-2 \\
(0.23 \mathrm{E}-2)\end{array}$ & $\begin{array}{c}-0.010^{* *} \\
(0.004) \\
\end{array}$ & $\begin{array}{c}-0.001 \\
(0.003) \\
\end{array}$ & $\begin{array}{c}0.014 \\
(0.020) \\
\end{array}$ & $\begin{array}{c}-0.73 \mathrm{E}-3 \\
(0.65 \mathrm{E}-3) \\
\end{array}$ & $\begin{array}{l}-0.001 \\
(0.002) \\
\end{array}$ & $\begin{array}{c}0.62 \mathrm{E}-3 \\
(0.84 \mathrm{E}-3)\end{array}$ & $\begin{array}{c}-0.072 \\
(0.262) \\
\end{array}$ & -0.044 \\
\hline $\begin{array}{l}\text { High Markup } \\
\text { (UK ranking) }\end{array}$ & $\begin{array}{c}1.105^{* * *} \\
(0.408) \\
\end{array}$ & $\begin{array}{c}0.63 \mathrm{E}-3 \\
(0.001)\end{array}$ & $\begin{array}{c}-0.008^{* *} \\
(0.003)\end{array}$ & $\begin{array}{c}-0.82 \mathrm{E}-3 \\
(0.18 \mathrm{E}-2) \\
\end{array}$ & $\begin{array}{c}0.011 \\
(0.012) \\
\end{array}$ & $\begin{array}{c}-0.37 \mathrm{E}-3 \\
(0.40 \mathrm{E}-3)\end{array}$ & $\begin{array}{l}-0.001 \\
(0.001) \\
\end{array}$ & $\begin{array}{c}0.32 \mathrm{E}-3 \\
(0.56 \mathrm{E}-3)\end{array}$ & $\begin{array}{r}-0.210 \\
(0.151) \\
\end{array}$ & 0.017 \\
\hline $\begin{array}{l}\text { Low Markup } \\
\text { (UK ranking) }\end{array}$ & $\begin{array}{l}2.946^{* *} \\
(1.482) \\
\end{array}$ & $\begin{array}{c}0.004 \\
(0.006) \\
\end{array}$ & $\begin{array}{c}-0.033 \\
(0.013) \\
\end{array}$ & $\begin{array}{c}0.011 \\
(0.009) \\
\end{array}$ & $\begin{array}{c}0.033 \\
(0.059) \\
\end{array}$ & $\begin{array}{c}-0.002 \\
(0.002) \\
\end{array}$ & $\begin{array}{l}-0.002 \\
(0.006)\end{array}$ & $\begin{array}{c}0.001 \\
(0.003)\end{array}$ & $\begin{array}{c}0.142 \\
(0.600)\end{array}$ & -0.057 \\
\hline
\end{tabular}

Each equation has been corrected for first order serial correlation. standard errors reported under the parameter estimates. ***,**,* Significant at the 1,5 and 10 percent level, 2-tailed test. 
as sectors rely more heavily on imported inputs into production. Once again, anticipated exchange rates do not appear to significantly influence overall markups.

Investment and Markups in Canada: In Canada investment in high markup industries are not statistically affected by exchange rate movements (Table 6). In low markup sectors the exchange rate is a statistically significant determinant of investment, but this effect is not qualitatively important. The sign of the coefficient on the interacted export share term is negative, not positive as observed for the other countries and expected from the theoretical exposition. Although this result is counterintuitive, it is a theoretical possibility under the elasticities interpretation. ${ }^{35}$ Markups in the groups of Canadian two-digit industries are unresponsive to both actual and anticipated exchange rates.

Comparison of results across countries and within industries: The results presented in Tables 3 through 6 use high and low markup classifications based on the rankings of sectors within each country. This treatment means that different industries are contained within the high and low markup groups of each country. Differences in investment responses across countries may be due to cross-country distinctions in the industry composition of the groups. To control for this possibility, we also tested whether our regression results for each country change when industries are pooled using the high versus low markup sector rankings of the United States. In fact, these new results are quite different from the results using own country sector rankings. Using United States rankings, investment responsiveness to exchange rates is generally insignificant or qualitatively unimportant for countries other than the United States. This contrasts sharply with the country tables in which there were clear patterns of differences

\footnotetext{
${ }^{35}$ If the weighted sums of the foreign market export price elasticity and the domestic price elasticity terms exceed the export valuation effect of the depreciation, this coefficient theoretically can take on a negative sign. The likelihood of this type of result is enhanced when domestic prices are highly responsive to real exchange rate movements and when domestic demand elasticities are relatively low.
} 
$\Delta l_{t}^{i}=\beta_{0}^{i}+\beta_{1} \Delta y_{t}^{i}+\left(\beta_{2}+\beta_{3} \chi_{t-1}^{i}+\beta_{4} \alpha_{t-1}^{i}\left(1-M K U P_{t-1}^{i}\right)\right) \Delta e_{t-1}+\left(\beta_{5}+\beta_{6} \chi_{t-1}^{i}+\beta_{7} \alpha_{t-1}^{i}\left(1-M K U P_{t-1}^{i}\right)\right) \Delta e_{t}^{a}+\beta_{8} \Delta r_{t}+\mu_{t}^{i}$

$\Delta M K U P_{t}^{i}=\delta_{0}^{i}+\delta_{1}^{i} \cdot \operatorname{trend}_{t}^{i}+\left(\delta_{2}+\delta_{3} \chi_{t-1}^{i}+\delta_{4} \alpha_{t-1}^{i}+\delta_{5} M_{t-1}^{i}\right) \Delta e_{t}+\left(\delta_{6}+\delta_{7} \chi_{t-1}^{i}+\delta_{8} \alpha_{t-1}^{i}+\delta_{9} M_{t-1}^{i}\right) \Delta e_{t+1}^{a}+\delta_{10} \Delta y_{t}^{i}+u_{t}^{i}$

\begin{tabular}{|c|c|c|c|c|c|c|c|c|c|c|}
\hline INVESTMENT & $\mathbf{e}$ & $\chi^{i} \cdot \mathrm{e}$ & $\begin{array}{c}\alpha^{i} \cdot(1-M K U P) \\
e \\
\end{array}$ & & $\mathrm{e}^{\mathbf{a}}$ & $\chi^{i} \cdot e^{a}$ & $\begin{array}{c}\alpha^{\mathbf{i}} \cdot(1-\mathrm{MKUP}) \\
\mathrm{e}^{\mathrm{a}}\end{array}$ & & $\begin{array}{c}\text { sales } \\
\text { growth }\end{array}$ & \\
\hline $\begin{array}{c}\text { All Industries } \\
\text { 3SLS } \\
\end{array}$ & $\begin{array}{r}-0.669 \\
(0.669) \\
\end{array}$ & $\begin{array}{c}-0.77 E-2 \\
(0.018) \\
\end{array}$ & $\begin{array}{c}0.060 \\
(0.048) \\
\end{array}$ & & $\begin{array}{l}-0.306^{*} \\
(0.171) \\
\end{array}$ & $\begin{array}{l}-0.56 \mathrm{E}-2 * \\
(0.33 \mathrm{E}-2)\end{array}$ & $\begin{array}{c}0.022 * * \\
(0.010)\end{array}$ & & $\begin{array}{c}0.405^{* *} \\
(0.201) \\
\end{array}$ & \\
\hline $\begin{array}{c}\text { High Markup } \\
\text { 3SLS }\end{array}$ & $\begin{array}{r}-1.071 \\
(1.089) \\
\end{array}$ & $\begin{array}{c}0.035 \\
(0.026) \\
\end{array}$ & $\begin{array}{c}0.041 \\
(0.066)\end{array}$ & & $\begin{array}{c}-0.321 \\
(0.271) \\
\end{array}$ & $\begin{array}{c}0.13 E-2 \\
(0.45 E-2)\end{array}$ & $\begin{array}{r}0.018 \\
(0.013) \\
\end{array}$ & & $\begin{array}{r}0.187 \\
(0.263) \\
\end{array}$ & \\
\hline $\begin{array}{c}\text { Low Markup } \\
\text { 3SLS } \\
\end{array}$ & $\begin{array}{r}-0.399 \\
(0.755) \\
\end{array}$ & $\begin{array}{c}-0.049 * * \\
(0.024) \\
\end{array}$ & $\begin{array}{c}0.088 \\
(0.067) \\
\end{array}$ & & $\begin{array}{r}-0.225 \\
(0.202) \\
\end{array}$ & $\begin{array}{l}-0.010^{* *} \\
(0.45 \mathrm{E}-2)\end{array}$ & $\begin{array}{c}0.024 \\
(0.018) \\
\end{array}$ & & $\begin{array}{c}0.860 * * * \\
(0.305)\end{array}$ & \\
\hline MARKUP & $\mathbf{e}$ & $\chi^{\mathbf{i}} \cdot e$ & $\alpha^{i} \cdot e$ & Mi.e & $\mathrm{e}^{\mathrm{a}}$ & $\chi^{i} e^{a}$ & $\boldsymbol{\alpha}^{\mathrm{i}} \cdot \mathrm{e}^{\mathrm{a}}$ & $\mathbf{M}^{\mathbf{i}} \cdot \mathrm{e}^{\mathrm{a}}$ & $\begin{array}{c}\text { sales } \\
\text { growth }\end{array}$ & $\begin{array}{l}\text { adj } \\
\text { R2 }\end{array}$ \\
\hline All Industries & $\begin{array}{r}-0.528 \\
(0.460) \\
\end{array}$ & $\begin{array}{c}0.58 \mathrm{E}-2 \\
(0.014)\end{array}$ & $\begin{array}{c}0.026 \\
(0.030)\end{array}$ & $\begin{array}{r}-0.44 \mathrm{E}-2 \\
(0.91 \mathrm{E}-2) \\
\end{array}$ & $\begin{array}{c}0.017 \\
(0.076) \\
\end{array}$ & $\begin{array}{c}-0.33 E-2 \\
(0.23 E-2) \\
\end{array}$ & $\begin{array}{l}-0.11 \mathrm{E}-2 \\
(0.44 \mathrm{E}-2)\end{array}$ & $\begin{array}{c}0.17 \mathrm{E}-2 \\
(0.14 \mathrm{E}-2)\end{array}$ & $\begin{array}{c}0.944^{* * *} \\
(0.178) \\
\end{array}$ & 0.11 \\
\hline $\begin{array}{l}\text { High Markup } \\
\text { (Can. ranking) }\end{array}$ & $\begin{array}{r}-1.318 \\
(0.862) \\
\end{array}$ & $\begin{array}{r}0.47 \mathrm{E}-2 \\
(0.029) \\
\end{array}$ & $\begin{array}{c}0.035 \\
(0.046) \\
\end{array}$ & $\begin{array}{c}0.94 \mathrm{E}-2 \\
(0.030)\end{array}$ & $\begin{array}{c}0.054 \\
(0.144) \\
\end{array}$ & $\begin{array}{c}-0.26 \mathrm{E}-2 \\
(0.46 \mathrm{E}-2)\end{array}$ & $\begin{array}{l}-0.39 \mathrm{E}-2 \\
(0.65 \mathrm{E}-2) \\
\end{array}$ & $\begin{array}{c}0.31 \mathrm{E}-2 \\
(0.46 \mathrm{E}-2)\end{array}$ & $\begin{array}{c}1.170^{* * * *} \\
(0.284)\end{array}$ & 0.09 \\
\hline $\begin{array}{l}\text { Low Markup } \\
\text { (Can. ranking) }\end{array}$ & $\begin{array}{r}0.116 \\
(0.488) \\
\end{array}$ & $\begin{array}{c}0.34 \mathrm{E}-2 \\
(0.015)\end{array}$ & $\begin{array}{r}0.012 \\
(0.057) \\
\end{array}$ & $\begin{array}{c}-0.65 E-2 \\
(0.014)\end{array}$ & $\begin{array}{r}-0.028 \\
(0.080) \\
\end{array}$ & $\begin{array}{c}-0.44 \mathrm{E}-2 \\
(0.24 \mathrm{E}-2)\end{array}$ & $\begin{array}{c}0.83 E-3 \\
(0.90 \mathrm{E}-2)\end{array}$ & $\begin{array}{c}0.14 \mathrm{E}-2 \\
(0.22 \mathrm{E}-2)\end{array}$ & $\begin{array}{c}0.575^{* * *} \\
(0.210)\end{array}$ & 0.10 \\
\hline
\end{tabular}

Each equation has been corrected for first order serial correlation. standard errors reported under the parameter estimates. ***,**,* Significant at the 1,5 and 10 percent level, 2-tailed test. 
of adjustment across high and low markup sectors. These results suggest that the markup rankings within countries are related to sectoral characteristics that impinge on investment elasticities with respect to exchange rates. Such characteristics could include industry concentration, relevant institutions for particular industries in a country, and the competition facing producers in their own markets.

As a final exercise, we run regressions for each two-digit sector, pooling data from the United States, Japan, Canada and the United Kingdom. This yields fourteen pooled sectors which have similar composition. The reported investment results are from a 2 SLS procedure in which instrumental variables techniques deal with the simultaneity of interest rates. Additive country dummy variables are introduced into each investment regression, but the coefficients on investment endogeneity with respect to exchange rates are assumed to be identical across countries, within each two-digit sector. The results of the industry regressions are summarized in Table 7.

When sectoral data is pooled across countries, exchange rates, actual and anticipated, are almost never statistically significant determinants of investment. For data pooled across countries, actual exchange rates enter into investment equations with at least one statistically significant coefficient for only 3 of the 14 sectors. Anticipated exchange rates are statistically significant for investment in only 2 sectors. There are no sectors in which investment is significantly influenced by both actual and anticipated exchange rate movements.

These pooled results show that it is clearly inappropriate to restrict the coefficients on the exchange rate terms to be identical across countries in the investment regressions. ${ }^{36}$ In comparison with the intra-country, cross-sectoral results discussed for Tables 3 to 6 , a strong conclusion emerges. Investment elasticities with respect to exchange rates are very much country-specific phenomenon. The results strongly suggest that country-specific features

\footnotetext{
${ }^{36} \mathrm{O}$ course, the cross-country results also could be weak because this exercise pools together investment series for industries which may be defined differently across countries.
} 
dominate investment responsiveness to exchange rates and to expected industry profitability. It is only for intra-country analyses that industry-specific features play the dominant role.

Table 7 Summary: Results from Pooling Data Across Countries by Sector Number of Two-Digit Sectors with a Statistically Significant Coefficient on Exchange Rate Exposure Terms, Out of a Total of 14 Sectors

\begin{tabular}{|c|c|c|c|}
\hline Actual Exchange Rate Terms & Investment & Markup & $\begin{array}{c}\text { Both Investment } \\
\text { and Markup }\end{array}$ \\
\hline $\begin{array}{l}\text { At least one significant from } \\
\text { among } e, e \cdot \chi_{j}, e \cdot \alpha_{j} \text { or } e \cdot \mathrm{M}_{i}\end{array}$ & 3 & 6 & 2 \\
\hline$e \cdot \chi_{i}$ significant & 0 & 1 & 0 \\
\hline$e \cdot \alpha_{i}$ significant & 2 & 2 & 0 \\
\hline$e \cdot \mathbf{M}_{i}$ significant & - & 2 & - \\
\hline Anticipated Exchange Rates & Investment & Markup & $\begin{array}{l}\text { Both Investment } \\
\text { and Markup }\end{array}$ \\
\hline $\begin{array}{l}\text { At least one significant from } \\
\text { among } e, e \cdot \chi_{i}, e \cdot \alpha_{j} \text { or } e \cdot \mathbf{M}_{j}\end{array}$ & 2 & 9 & 2 \\
\hline$e \cdot \chi_{i}$ significant & 1 & 8 & 1 \\
\hline$e \cdot \alpha_{i}$ significant & 2 & 5 & 1 \\
\hline$e \cdot \mathbf{M}_{i}$ significant & - & 3 & $\ldots$ \\
\hline
\end{tabular}


In contrast to these investment results, the sectoral markup regressions summarized in Table 7 show that markups have very strong sectoral endogeneity with respect to exchange rates. Actual exchange rates significantly affect markups in 6 of 14 sectors; anticipated exchange rates influence markups in 9 of 14 sectors. A very consistent pattern of markup endogeneity emerged with respect to anticipated exchange rate movements. The interacted export share terms always had a negative coefficient when it was significantly different from zero (for 8 of 14 sectors). The interacted imported input share terms always had a negative coefficient when it differed significantly from zero (in 5 of 14 sectors). Import competition tended to reduce markups, but this effect was statistically significant only for 2 sectors. Our results on markup endogeneity with respect to exchange rates are consistent with the Froot and Klemperer (1989) hypothesis about dynamic competition for market share. These results show up more consistently in sectoral data than in data which pooled different sectors together within a country. However, despite this support, the quantitative importance of these effects remains very low.

\section{SECTION V: CONCLUDING REMARKS}

In this paper we have provided evidence on the effects that real exchange rate movements have on investment activity in the United States, Japan, the United Kingdom, and Canada. These effects evolve with the changing export exposure and imported input exposure of the producers. The importance of each of the exposure channels depends on a set of passthrough and demand elasticities. Specifically, the exposure of producer profitability and investment to exchange rates: (1) declines to the extent that exporters pass-through exchangerate movements into the local currency prices of their exports; (2) increases in relation to the price elasticity of foreign demand; (3) increases in relation to the exchange rate elasticity of producer prices in domestic markets; (4) declines in relation to the price elasticity of demand in domestic markets; and (5) declines (or becomes increasingly negative) to the extent that the producer relies on imported inputs into production and to the extent that exchange rates 
movements are passed through into the domestic currency price of these imported inputs. The empirical results support our basic model of investment, wherein the positive effects of depreciation on an industry are increasing in export share and decreasing in imported input share.

Across countries, exchange rates tend to have weak or relatively insignificant effects on investments in high markup sectors. By contrast, in the United States and Japan, investment responsiveness to exchange rates is fairly strong in the low markup sectors. This is a plausible result which has its roots in the comparison of pass-through coefficients and demand elasticities across high and low markup sectors. In low markup sectors, the coefficients on the channels of exchange rate exposures are lower in Japan than in the United States. This result also is quite plausible if Japanese markets are more protected from foreign competition than United States markets, and if Japanese producers alter domestic prices to smooth overall production profitability. The results also are consistent with the view that investment activity in Japan is relatively unresponsive to short horizon (one to two year) patterns in producer profitability. Anticipated exchange rate movements are not as important for investment activity as are observed movements. One might expect this to be observed since exchange rate changes are perceived to be permanent and poorly predicted by the markets.

Investment endogeneity has strong country-specific tendencies. Investment responses to exchange rate movements, and to changes in producer profitability, are not similar across countries, within sectors. This finding is in direct contrast with the behavior of price-overcost markups. As shown by our work and that of Knetter (1993), markup endogeneity with respect to exchange rates is more of an industry-specific phenomenon. These findings suggest that country-specific characteristics be further explored in discussions of the real implications of exchange rate movements. One potentially interesting direction for future work could focus on cross-country differences in the ability of producers to hedge against volatility of profits, however induced. 


\section{REFERENCES}

Abel, A. and O. Blanchard, 1986, The present value of profits and cyclical movements in investment, Econometrica 54, 249-273, March.

Bartov, E. and G. Bodnar, 1994, Firm Valuation, Earnings Expectations, and the Exchange Rate Exposure Effect, Journal of Finance vol.49 no.6 (December) 1755-1786.

Bodnar, G. and W. Gentry, 1993, Exchange rate exposure and industry characteristics: evidence from Canada, Japan, and the USA, Journal of International Money and Finance 12, 29-45.

Branson, W. and J. Love, 1988, United States Manufacturing and the Real Exchange Rate, in R. Marston, ed., Misalignment of Exchange Rates: Effects on Trade and Industry, University of Chicago Press.

Branson, W. and R. Marston, 1989, Price and output adjustment in Japanese manufacturing, National Bureau of Economic Research working paper 2878.

Campa, J., 1993, Entry by foreign firms in the United States under exchange rate uncertainty, Review of Economics and Statistics, vol. LXXV no.4, November, 614-622.

Campa, J. and L. Goldberg, 1995a, Investment, exchange rates and external exposure, Journal of International Economics, forthcoming.

Campa, J. and L. Goldberg, 1995b, Exchange rates and sectoral exposure: A comparison of the United States, Japan, Canada and the United Kingdom, manuscript, New York University.

Clarida, R., 1993, The real exchange rate and US manufacturing profits: a theoretical framework with some empirical support, manuscript, Columbia University (March).

Domowitz, I., Hubbard, G. and B. Petersen, 1986, Business cycles and the relationship between concentration and price-cost margins, Rand Journal of Economics 17, 1-17, Spring.

Dornbusch, R., 1987, Exchange rates and prices, American Economic Review 77, 93-106, March.

Feinberg, R., 1986, The interaction of market power and exchange rate effects on German domestic prices, Journal of Industrial Economics, 35, 61-70.

Feinberg, R., 1989, The effects of foreign exchange movements on United States domestic prices, Review of Economics and Statistics 71, 505-511.

Frankel, J. and K. Froot, 1989, Using Survey Data to Test Standard Propositions Regarding Exchange Rate Expectations, American Economic Review, March, 77, 133-53.

Froot, K. and P. Klemperer, 1989, Exchange Rate Pass-Through When Market Share Matters, American Economic Review, September, 637-654.. 
Gertler, M. and S. Gilchrist, 1994, Monetary policy, business cycles, and the behavior of small manufacturing firms, Quarterly Journal of Economics, vol. 109 no.436, 309-340.

Goldberg, L., 1993, Exchange rates and investment in United States industry, Review of Economics and Statistics, vol. LXXV no.4, November, 575-588.

Goldberg, L., 1990, Measuring external openness: the Index of Effective Exposure. C.V. Starr Center working paper 90-19, May.

Goldberg, L. and C. Kolstad, 1995, Foreign direct investment, exchange rate variability, and demand uncertainty, International Economic Review, May.

Gordon, R., 1987, Productivity, wages, and prices inside and outside of manufacturing in the US, Japan and Europe, European Economic Review, vol.31.

Hall, R., 1988, The relation between price and marginal cost in U.S. industry, Journal of Political Economy 96, 921-947, October.

Ito, T., Foreign exchange expectations: micro survey data, American Economic Review 80, 434-449, June.

Knetter, M., 1989, Price discrimination by U.S. and German exporters, American Economic Review 79, 198-210, March.

Knetter, M., 1993, International comparisons of pricing-to-market behavior, American Economic Review 83, 473-486, June.

Knetter, M., 1994, Why are retail prices in Japan so high?: Evidence from German Export Prices. National Bureau of Economic Research working paper \#4894 (October).

Krugman, P., 1987, Pricing to market when the exchange rate changes," in Real-Financial Linkages among Open Economies, ed. Amdt and Richardsson (Cambridge, MA.: MTT Press).

Mann, C., 1986, Prices, profit margins, and exchange rates, Federal Reserve Bulletin 72, 36679 , June.

Mann, C., 1994. Foreign influences on U.S. inflation: further investigation of aggregate and disaggregated measures. memo, Board of Governors of the Federal Reserve System.

Marston, R., 1990, Pricing to market in Japanese manufacturing, Journal of International Economics 29, 217-236, November.

Phelps, E. and S. Winter, 1970, Optimal price policy under atomistic competition, in Macroeconomic Foundations of Employment and Inflation Theory, E. Phelps ed., New York: W.W. Norton.

Rotemberg, J. and G. Saloner, 1986, A supergame-theoretic model of price wars during booms, American Economic Review, 76, June, pp.390-407.

Swagel, P., 1995, Import Prices and the Competing Goods Effect, Board of Governors of the Federal Reserve System, discussion paper \#508 (April). 
Appendix Table 1: Industry Indicators of External Activity within Each Country

\begin{tabular}{|c|c|c|c|c|c|c|c|c|c|c|c|c|}
\hline \multirow[b]{2}{*}{ Sector } & \multicolumn{3}{|c|}{ United States (1) } & \multicolumn{3}{|c|}{ Canada (2) } & \multicolumn{3}{|c|}{ UK (3) } & \multicolumn{3}{|c|}{ Japan (4) } \\
\hline & $x_{\mathbf{i}}$ & $\alpha_{i}$ & $\mathbf{M}_{\mathbf{i}}$ & $x_{i}$ & $\alpha_{i}$ & $\mathbf{M}_{\mathbf{i}}$ & $\chi_{\mathrm{i}}$ & $\alpha_{i}$ & $\mathbf{M}_{\mathbf{i}}$ & $\chi_{\mathbf{i}}$ & $\alpha_{i}$ & $\mathbf{M}_{\mathbf{i}}$ \\
\hline Food and Kindred Products (7) & 4.07 & 4.21 & 4.04 & 9.89 & 6.16 & 11.28 & 6.16 & 8.24 & 18.79 & 0.89 & 7.03 & 7.02 \\
\hline Tobacco Manufactures & 9.00 & 2.16 & 0.96 & 7.28 & 5.40 & 3.32 & 23.04 & 8.88 & 14.29 & & & \\
\hline Textile Mill Products (8) & 4.62 & 5.16 & 5.54 & 9.13 & 18.38 & 47.07 & 19.53 & 22.32 & 29.89 & 7.66 & 4.24 & 8.14 \\
\hline Apparel and Other Mill Products & 2.27 & 4.51 & 13.34 & 5.12 & 21.54 & 32.3 & & & & & & \\
\hline Lumber and Wood Products (9) & 6.32 & 5.32 & 9.28 & 43.79 & 2.78 & 7.13 & 1.94 & \begin{tabular}{|l|}
19.64 \\
\end{tabular} & 30.95 & 0.80 & 5.32 & 7.09 \\
\hline Furniture and Fixtures & 1.64 & 7.20 & 5.02 & 12.12 & 9.50 & 17.54 & 7.15 & 17.00 & 11.00 & & & \\
\hline Paper and Allied Products & 5.15 & 6.28 & 6.39 & 52.84 & 4.58 & 8.19 & 7.32 & 20.51 & 29.43 & 2.52 & 2.66 & 4.15 \\
\hline Printing and Publishing & 1.52 & 4.81 & 1.03 & 3.76 & 3.58 & 15.13 & 7.50 & 11.87 & 4.73 & 0.59 & 1.19 & 0.73 \\
\hline Chemicals and Allied Products & 11.19 & 4.85 & 4.55 & 7.30 & 10.82 & 34.14 & 34.89 & 16.99 & 26.75 & 9.08 & 4.03 & 6.82 \\
\hline Petroleum and Coal Products & 2.16 & 7.73 & 8.74 & 14.32 & 44.37 & 9.05 & 17.39 & 4.58 & 17.72 & 2.38 & 46.72 & 12.44 \\
\hline Rubber and Plastics Products (10) & 4.45 & 4.83 & 5.49 & 12.71 & 13.78 & 31.71 & 9.48 & 18.21 & 13.69 & 13.52 & 3.13 & 5.71 \\
\hline Leather and Leather Products 11) & 4.64 & 14.31 & 29.52 & 7.74 & 19.62 & 74.18 & 18.14 & 20.58 & 32.45 & & & \\
\hline Stone, Clay and Glass & 3.58 & 5.14 & 5.09 & 10.67 & 6.60 & 21.21 & 11.03 & 10.31 & 8.65 & 5.38 & 11.12 & 1.80 \\
\hline Primary Metal Products (5) & 4.11 & 9.82 & 12.19 & 33.12 & 13.9 & 17.34 & 17.87 & 14.03 & 16.77 & 11.29 & 4.30 & 1.56 \\
\hline Fabricated Metal Products & 5.48 & 9.07 & 3.83 & 10.41 & 9.40 & 24.15 & 15.94 & 18.36 & 21.42 & 7.28 & 2.02 & 1.08 \\
\hline Nonelectrical Machinery & 20.47 & 8.40 & 8.56 & 51.27 & 35.46 & 58.47 & 45.57 & 20.98 & 35.34 & 17.14 & 1.77 & 2.79 \\
\hline Electrical Machinery & 11.00 & 8.90 & 11.90 & 21.83 & 22.33 & 60.57 & 24.34 & 20.35 & 26.17 & 21.64 & 2.81 & 3.43 \\
\hline Transportation Equipment & 13.28 & 10.00 & 13.27 & 69.30 & 38.61 & 78.00 & 36.69 & 21.50 & 31.97 & 28.24 & 2.23 & 2.22 \\
\hline Instruments and Related Prod. (6) & 16.50 & 7.97 & 10.13 & & & & 78.77 & 18.59 & 74.46 & 32.33 & 4.07 & 11.43 \\
\hline
\end{tabular}

Notes: (1) Average for 1972 to 1986; (2) Average for 1974-1991; (3) Average for 1974-1990; (4) Average for 1974 to 1990 ; (5) For United Kingdom and Japan excludes nonferrous metals; (6) For Japan excludes professional goods; (7) for United Kingdom excludes beverages; (8) for United Kingdom includes wearing apparel; (9) for Japan includes lumber, wood, and furniture; (10) for Japan includes leather and for United Kingdom excludes rubber; (11) for United Kingdom includes Footware. Miscellaneous manufacturing excluded from table for all countries. 


\section{Appendix: The Data}

Japan: Japan Input-Output Tables Extended Chart by International Trade and Industry Statistics Association. Contains 1974-1990 data on annual input-output as well as exports, imports, wages and salaries, total production, material costs and value added, all nominal measured in millions of Japanese yen. From Japan Statistical Yearbook by Statistics Bureau of the Prime Ministers Office are data on investments in equipment by industry are survey data on all incorporated businesses with a capital or a subscription of 100 million or more and with its head or main office in Japan. Other data are from various issues of International Financial Statistics, including real effective exchange rates (relative unit labor costs) and interest rates on long term government bonds.

Canada: The Input-Output Structure of the Canadian Economy by Statistics Canada are nominal data in millions of Canadian dollars, 1974-1990. Also from this source are data on exports, imports, wages and salaries, total production, materials costs and value added. Data on investments are from CANSIM, a computer database organization sponsored by Statistics Canada. Data on investment for Tobacco Products is missing due to confidentiality. Other data are from various issues of Intemational Financial Statistics, including real effective exchange rates and interest rates on long term government bonds.

United Kingdom: Only one year of input-output data is used in our calculations, i.e. 1990 Input-Output Balances for the United Kingdom by Central Statistical Office of the United Kingdom (1993). Data on total investment, investment in equipment and machinery, exports, imports, wages and salaries, employees' social security costs, total production, and value added are from Industrial Structure Statistics by OECD. All data are in millions of British pounds. Other data are from various issues of Intermational Financial Statistics, including real effective exchange rates, wholesale price index, and interest rates on long term government bonds.

United States data: Only one year of input-output data is used in our calculations, i.e. 1982 Input-Output. Domestic investment is New Capital Expenditures by manufacturing industry. Source: Census of Manufactures, and Annual Survey of Manufactures from the Census Bureau. Industry sales data are from the US Department of Commerce. All expenditure figures are reported in constant 1982 dollars. The exchange rate series is from the Federal Reserve Bank of Dallas, series RX101. In each period we use the real exchange rate in the fourth quarter of year t. $1985=100$. The ten-year Treasury note comes from the U.S. Department of Commerce.

\section{Construction of Anticipated Real Exchange Rate Movements:}

Antipated rates of real exchange rate depreciation are constructed as the difference between the home country real twelve month interest rate and a trade-weighted (exports plus imports) average of the real interest rates of main (top 5 or 6) non-oil producing trading partners of each country. For the United States, these partners are Canada, Japan, Mexico, the United Kingdom (plus Netherlands), and France. For Canada, these partners are the United States, Japan, the United Kingdom, Germany (plus the Netherlands), and France. For the United 
Kingdom, the partners are the United States, Germany (plus the Netherlands), France, Belgium, and Ireland. For Japan, the partners are the United States, Germany (plus the Netherlands), Canada, Australia, and Korea. The trade weights are constant over the sample, and are based on 1980 data. For Japan, our selection of countries understates the importance of the rest of Asia as trading partners, especially China and Singapore. The annualized nominal interest rates for the United States, United Kingdom, Germany, Canada, France, Belgium, and Ireland are Eurorates. Due to data limitations, for Korea we use IFS line 61, "the arithmetic average of yields by maturity on Type 1 national housing bonds. For Australia we use IFS line 61a, the short term government bond yield (on two year bonds). For Mexico we use an average yield on 3 month Treasury Bills, available from 1978 through 1987, and thereafter the average yield on 1 month Treasury Bills. For the earlier part of the sample (when short term market-determined yields are unavailable), Mexico takes on a zero weight in our indices.

Specific equations for construction of price over cost markup ratios:

Japan: MKUP= $($ Total Value of Production - Employees' Compensation-Material Costs $) /$ (Total Value of Production).

Canada: MKUP= (Value Added - Employees' Compensation) $/$ (Total Value of Production).

United Kingdom: MKUP= (Value Added - Employees' Wages and Salaries-Employees' Social Security Costs)/ (Total Value of Production).

United States: MKUP= (Value added -Employee Compensation)/ (Total Value of Production). 